\title{
Caspase-dependent deubiquitination of monoubiquitinated nucleosomal histone H2A induced by diverse apoptogenic stimuli
}

\author{
EG Mimnaugh $^{\star, 1}$, G Kayastha ${ }^{1}$, NB McGovern ${ }^{1}$, S-G Hwang ${ }^{2}$, \\ MG Marcu ${ }^{1}$, J Trepel $^{2}$, S-Y Cai ${ }^{3}$, VT Marchesi ${ }^{3}$ and L Neckers ${ }^{1}$ \\ ${ }^{1}$ Tumor Cell Biology Section, Center for Cancer Research, National Cancer \\ Institute, NIH, Bethesda, MD 20892, USA \\ ${ }^{2}$ Cell Signaling and Oncogenesis Section, Cell and Cancer Biology Branch, \\ Center for Cancer Research, National Cancer Institute, NIH, Bethesda, MD \\ 20892, USA \\ 3 Yale University School of Medicine, New Haven, CT 06536, USA \\ * Corresponding author: EG Mimnaugh, Tumor Cell Biology Section, Medicine \\ Branch, National Cancer Institute, NIH Key West Center, Suite 300, 9610 \\ Medical Center Drive, Rockville, MD 20850, USA. Tel: (301) 402-3128; \\ Fax: (301) 402-4422; E-mail: edmim@box-e.nih.gov
}

Received 4.12.00; revised 11.4.01; accepted 6.2.01

Edited by L Schwartz

\begin{abstract}
Enzymatic deubiquitination of mono-ubiquitinated nucleosomal histone $\mathrm{H} 2 \mathrm{~A}(\mathrm{uH} 2 \mathrm{~A}$ ) and $\mathrm{H} 2 \mathrm{~B}$ (uH2B) is closely associated with mitotic chromatin condensation, although the function of this histone modification in cell division remains ambiguous. Here we show that rapid and extensive deubiquitination of nucleosomal uH2A occurs in Jurkat cells undergoing apoptosis initiated by anti-Fas activating antibody, staurosporine, etoposide, doxorubicin and the proteasome inhibitor, $\mathrm{N}$-acetyl-leucyl-leucyl-norlucinal. These diverse apoptosis inducers also promoted the accumulation of slowly migrating, high molecular weight ubiquitinated proteins and depleted the cellular pool of unconjugated ubiquitin. In apoptotic cells, ubiquitin was cleaved from uH2A subsequent to the appearance of plasma membrane blebbing, and deubiquitination of uH2A closely coincided with the onset of nuclear pyknosis and chromatin condensation. Nucleosomal uH2A deubiquitination, poly (ADP-ribose)polymerase (PARP) cleavage and chromatin condensation were prevented in cells challenged with apoptosis inducers by pretreatment with the pan-caspase inhibitor, zVAD-fmk, or by over-expressing antiapoptotic $\mathrm{Bcl}-\mathrm{xL}$ protein. These results implicate a connection between caspase cascade activation and nucleosomal uH2A deubiquitination. Transient transfection of 293 cells with the gene encoding Ubp-M, a human deubiquitinating enzyme, promoted uH2A deubiquitination, while an inactive mutated Ubp-M enzyme did not. However, Ubp-M-promoted deubiquitination of uH2A was insufficient to initiate apoptosis in these cells. We conclude that uH2A deubiquitination is a downstream consequence of procaspase activation and that unscheduled cleavage of ubiquitin from uH2A is a consistent
\end{abstract}

feature of the execution phase of apoptosis rather than a determining or initiating apoptogenic event. Nucleosomal uH2A deubiquitination may function as a cellular sensor of stress in situations like apoptosis through which cells attempt to preserve genomic integrity. Cell Death and Differentiation (2001) 8, 1182-1196.

Keywords: ubiquitin; histones; nucleosomes; caspases; deubiquitination; apoptosis

Abbreviations: AIF, apoptosis inducing factor; ALLnL, N-acetylleucyl-leucyl norlucinal; AUT, $0.96 \mathrm{~N}$ acetic acid, $6.7 \mathrm{M}$ urea, $6 \mathrm{mM}$ Triton X-100; DAPI, 4,6-diamidino-2-phenylindole; ERCC-1, excision repair cross-complementation group-1; PBS, phosphatebuffered saline; GFP, green fluorescent protein; PARP, poly(ADPribose) polymerase; Ubp-M, human deubiquitinating enzyme; $\mathrm{uH} 2 \mathrm{~A}$, monoubiquitinated nucleosomal histone H2A; uH2B, monoubiquitinated histone H2B; VP-16, etoposide

\section{Introduction}

The enzymatic mono-ubiquitination of lysine residues in the C-terminal tails of nucleosomal histones $\mathrm{H} 2 \mathrm{~A}$ and $\mathrm{H} 2 \mathrm{~B}$ is a novel modification associated with changes in chromatin structure. Although poly-ubiquitination of cellular proteins usually targets them for proteasomal degradation, histone mono-ubiquitination does not constitute a degradation signal. ${ }^{1-3}$ Consequently, histones are extremely stable, and neither histone $\mathrm{H} 2 \mathrm{~A}$ nor $\mathrm{H} 2 \mathrm{~B}$ are appreciably degraded during the lives of most cells. ${ }^{4}$ The ubiquitin status of nucleosomal histones, however, is balanced in a dynamic equilibrium where the ubiquitin moiety exchanges freely within intact nucleosomes. ${ }^{5,6}$ Heterogeneously distributed within chromatin, uH2A-containing nucleosomes are particularly enriched within loosely-structured, transcriptionallyactive euchromatin, while in the highly-ordered heterochromatin, nucleosomal histones are essentially ubiquitin-free. ${ }^{2}$ Provocatively, ubiquitin is cleaved from $\mathrm{uH} 2 \mathrm{~A}$ and $\mathrm{uH} 2 \mathrm{~B}$ during mitosis as cells move from prophase to metaphase and chromatin condenses into chromosomes. Nucleosomal histones $\mathrm{H} 2 \mathrm{~A}$ and $\mathrm{H} 2 \mathrm{~B}$ are re-ubiquitinated quickly thereafter during anaphase. ${ }^{7,8}$ Although the regulation of mitotic histone ubiquitination/deubiquitination cycling remains a poorly understood phenomenon, a human deubiquitinating enzyme (Ubp-M), capable of cleaving ubiquitin from $\mathrm{UH} 2 \mathrm{~A}$ in vitro, has recently been implicated as a participant in mitotic chromatin condensation in that a mutated, enzymaticallyinactive version of the Ubp-M enzyme associates strongly with mitotic chromosomes and effectively blocks cell cycling. ${ }^{9}$ 
In addition to its putative role in mitotic chromosome condensation, $\mathrm{uH} 2 \mathrm{~A}$ deubiquitination appears to be a feature of condensing chromatin during $\mathrm{TGF}_{1}$-induced apoptosis in glioma cells. ${ }^{10}$ In addition, uH2A has been observed to decline coincident with apoptotic chromatin condensation in lymphoma cells undergoing proteasome inhibitor-induced apoptosis. ${ }^{11}$ We have previously reported that proteasome inhibitors and cellular stress-provoking agents, including several that induce apoptosis, promote rapid and complete $\mathrm{uH} 2 \mathrm{~A}$ deubiquitination in $\mathrm{SKBr}-3$ breast carcinoma cells and in isolated human lymphocytes. ${ }^{12}$ Furthermore, proteasome inhibitor-induced $\mathrm{uH} 2 \mathrm{~A}$ deubiquitination is associated with diminished ERCC-1-dependent nucleotide excision repair of cisplatin-DNA lesions and enhanced drug-initiated apoptosis in ovarian carcinoma cells, presumably in response to changes in chromatin structure. $^{13}$ Thus, several unrelated lines of evidence indicate that deubiquitination of nucleosomal histone $\mathrm{uH} 2 \mathrm{~A}$ is associated with modifications of chromatin structure that occur during normal cell division and in certain pathological situations.

We report here that deubiquitination of nucleosomal $\mathrm{uH} 2 \mathrm{~A}$ is a biochemical modification that closely coincides with the onset of the apoptotic morphological changes of plasma membrane blebbing and nuclear pyknosis in cells treated with diverse-acting apoptogenic agents. Independent of the mechanism of the apoptotic stimulus, deubiquitination of $\mathrm{uH} 2 \mathrm{~A}$, procaspase-3 activation, poly(ADP-ribose) polymerase (PARP) cleavage and chromatin condensation were prevented by the pan-caspase inhibitor, z-FAD-fmk, and by Bcl-xL over-expression. Together these observations suggest that caspase-dependent, enzymatic deubiquitination of nucleosomal $\mathrm{uH} 2 \mathrm{~A}$ may be a consistent feature of eukaryotic cells undergoing apoptosis.

\section{Results}

\section{Cell morphology after treatment with various apoptosis-inducing agents}

To identify the onset and to follow the progression of apoptosis in Jurkat cells treated with apoptosis-inducing agents we monitored the time course of cellular plasma membrane blebbing and chromatin condensation by phase contrast light microscopy. The concentrations of the apoptogenic agents that were used for morphology evaluations were selected from preliminary experiments. In general, plasma membrane blebbing was the first morphological alteration that was observed in cells after each of the treatments. Plasma membrane blebbing was biphasic in all cases, whether cells were treated with doxorubicin, etoposide, staurosporine, ALLnL or anti-Fas antibody (Figure $1 \mathrm{~A}-\mathrm{E}$ ). Note that the ordinates differ in the various panels. After peaking at between 20 and $60 \%$ of total cells, depending upon the apoptosis initiator, cell membrane blebbing diminished as apoptosis progressed and cells began to condense and fragment into apoptotic bodies. Nuclear pyknosis and chromatin condensation occurred concurrently or within a few hours of the initiation of membrane blebbing, and, in most cases, chromatin condensation became extensive, eventually occurring in $\sim 95 \%$ of cells (Figure $1 \mathrm{~A}-\mathrm{E}$ ). When chromatin condensation was pronounced, chromatin fragmentation and abundant apoptotic bodies were also observed by light microscopy. The shaded arrows in the panels of Figure 1 indicate the time when membrane blebbing was near maximum and chromatin condensation was easily observable. Notably, the percentage of viable cells at those times remained quite high ( $90 \%$ or more), as estimated by their ability to exclude Trypan blue dye. By the end of the experiments, however, the percentage of cells taking up the dye ranged from $10 \%$ to as high as $60 \%$ (Figure $1 \mathrm{~A}-\mathrm{E}$ ). The highest concentration of DMSO used was $0.5 \%$, which did not affect any of the measurements in this study. All of the agents that were used to induce apoptosis caused plasma membrane blebbing and chromatin condensation in Jurkat cells, although the time of the first appearance of these morphological features varied considerably (Figure 1A-E).

\section{Evaluation of chromatin condensation by DAPI staining}

To verify that the various treatments caused chromatin condensation, cells were exposed to apoptosis inducers and $12 \mathrm{~h}$ later they were stained with DAPI and examined by fluorescence microscopy. As shown in Figure 2A-D, extensive chromatin condensation and chromatin fragmentation are apparent in cells exposed to staurosporine, ALLnL, etoposide, and anti-Fas activating antibody. In control cells (Figure 2A,E), chromatin was evenly distributed throughout the nucleus and DAPI staining of DNA was less intense than in apoptotic cells. The contrast between DAPI-stained chromatin in control and apoptotic cells is most easily observed in panel $\mathrm{D}$, where etoposide-treated cells undergoing apoptosis have extensively condensed, fragmented and heavily DAPI-stained chromatin, while cells not yet apoptotic have essentially normal appearing ovoid nuclei with weakly stained chromatin. Each of the apoptosis-inducing agents promoted extensive chromatin condensation in Jurkat cells when evaluated by DAPI staining.

\section{Deubiquitination of uH2A and PARP cleavage during apoptosis}

To investigate the relationship between PARP cleavage and $\mathrm{uH} 2 \mathrm{~A}$ deubiquitination, we examined the response of cells to increasing concentrations of doxorubicin, staurosporine, etoposide and ALLnL. In this series of experiments, $u H 2 A$ deubiquitination occurred at concentrations of the apoptosisinducers that were equal to or slightly higher than those causing significant PARP cleavage at the selected times (Figure $3 A-D$ ). Overall, a close correlation between PARP cleavage and $\mathrm{uH} 2 \mathrm{~A}$ deubiquitination was found in cells undergoing apoptosis caused by each of the apoptosisinducing agents. Thus, $5 \mu \mathrm{M}$ doxorubicin for $14 \mathrm{~h}, 0.5 \mu \mathrm{M}$ staurosporine for $6 \mathrm{~h}, 2 \mu \mathrm{M}$ etoposide for $24 \mathrm{~h}$ and $50 \mu \mathrm{M}$ ALLnL for $4 \mathrm{~h}$ induced substantial PARP cleavage and nearly complete deubiquitination of $\mathrm{uH} 2 \mathrm{~A}$. These findings raise the possibility of a cause-and-effect relationship between caspase cascade activation and $\mathrm{uH} 2 \mathrm{~A}$ deubiquitination in cells undergoing apoptosis. 
A

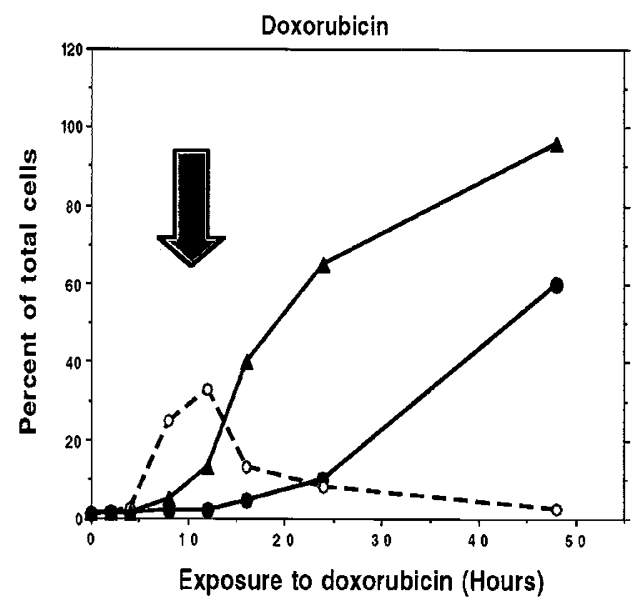

C

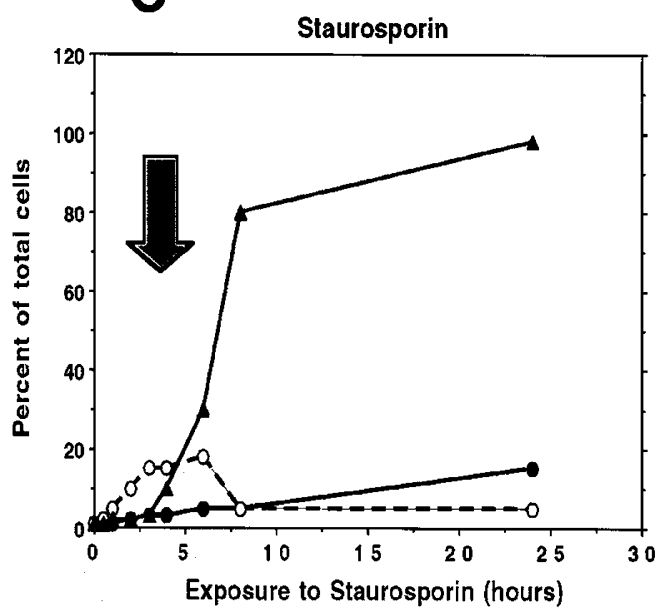

B
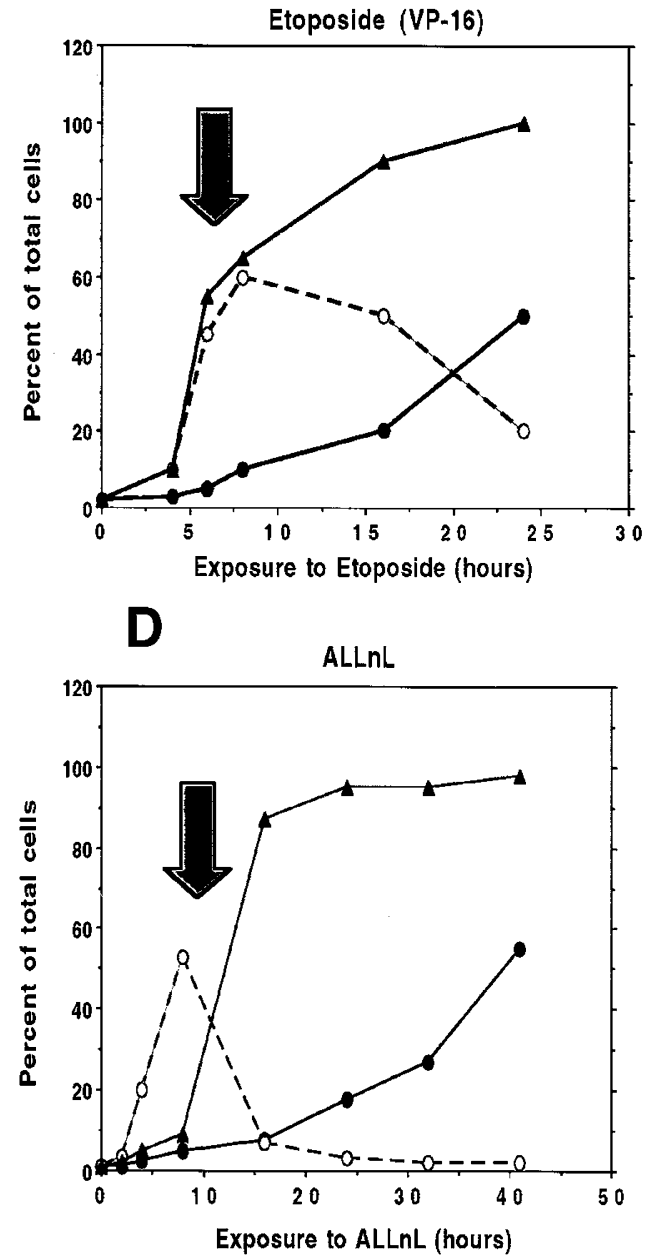

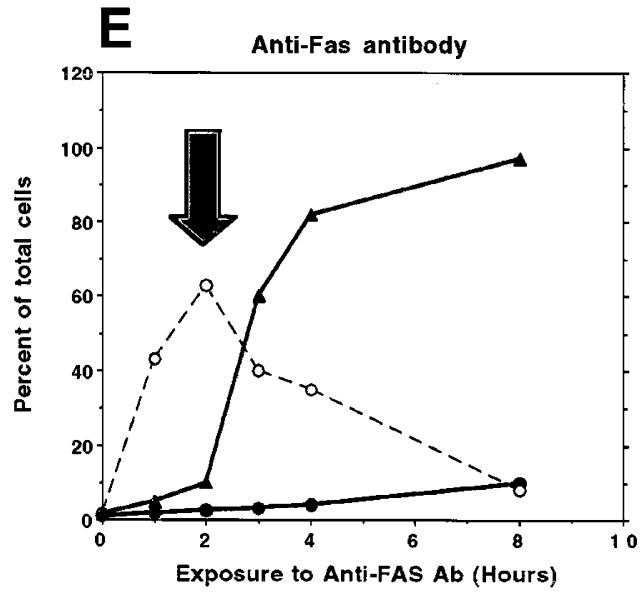

Figure 1 Morphological changes during apoptosis. Exponentially growing Jurkat cells were treated with $5 \mu \mathrm{M}$ doxorubicin (A), $10 \mu \mathrm{M}$ etoposide (B), $1 \mu \mathrm{M}$ staurosporine (C), $100 \mu \mathrm{M} \mathrm{ALLnL}$ (D) or $100 \mathrm{ng} / \mathrm{ml}$ anti-Fas activating antibody (E) for the indicated times. Stock solutions of etoposide, staurosporine and ALLnL were prepared in DMSO and control cells were exposed to $0.5 \%$ DMSO, the highest concentration used, for equivalent times. Morphological changes were monitored in aliquots of cells in the presence of Trypan blue dye, and the percentage of cells with plasma membrane blebbing (open circles), and chromatin condensation (closed triangles) as well as Trypan blue positive cells (closed circles) were determined by counting cells in several fields. Membrane blebbing was the initial morphological change indicating the onset of apoptosis, and the proportion of cells with membrane blebbing increased rapidly, then decreased as cells condensed and/or fragmented into apoptotic bodies. Extensive plasma membrane blebbing and chromatin condensation were observed well before appreciable cell death occurred, as estimated by Trypan blue dye positive staining of nuclei. The arrows indicate the earliest times when both plasma membrane blebbing and chromatin condensation were conspicuous in cells exposed to apoptosis-initiating agents 

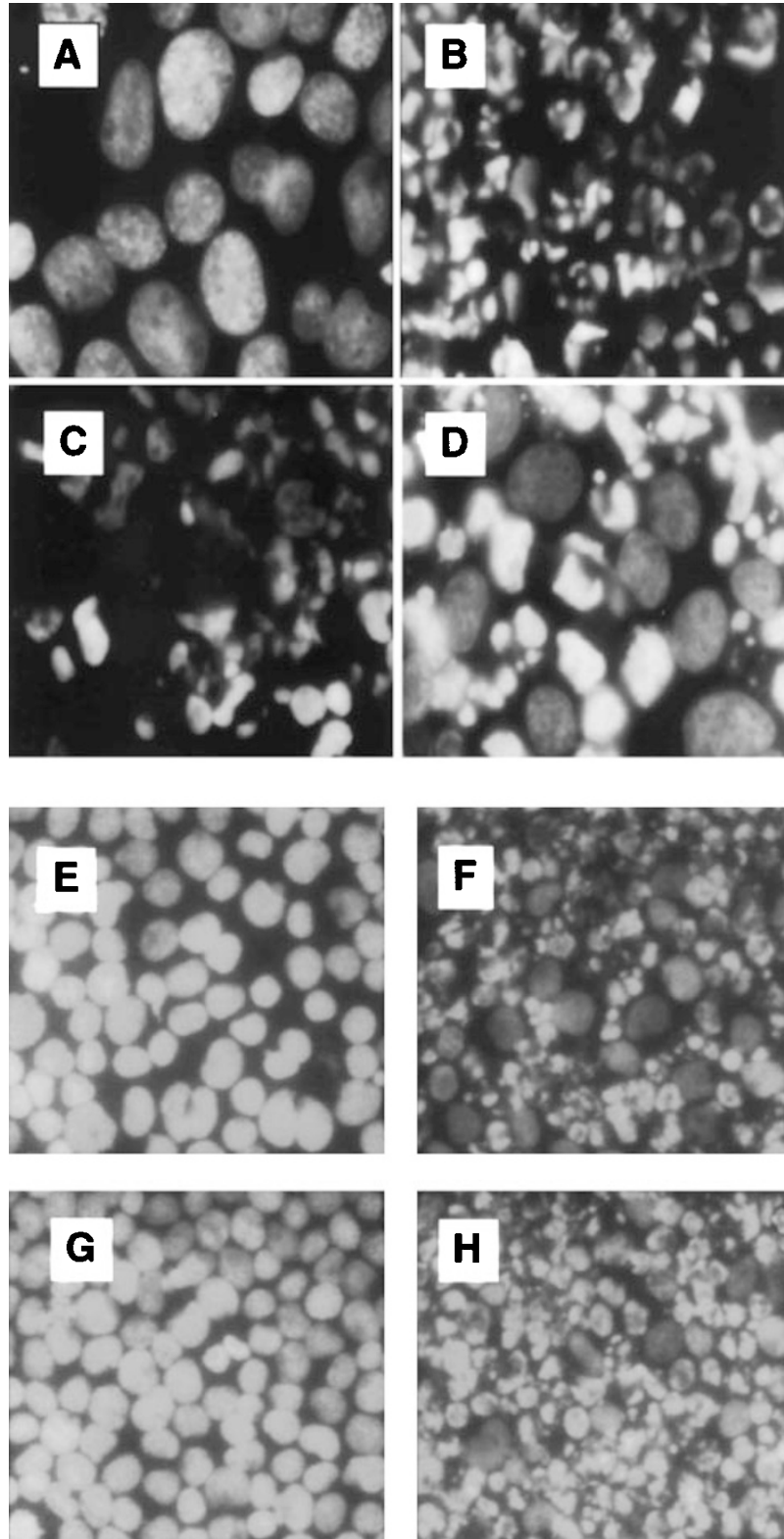

Figure 2 DAPI evaluation of chromatin condensation in cells undergoing apoptosis. Jurkat cells growing on glass cover-slips were exposed to apoptogenic agents or $0.5 \%$ DMSO, then $12 \mathrm{~h}$ later, the medium was aspirated and replaced with DAPI-containing $(1 \mu \mathrm{g} / \mathrm{ml})$ complete medium. The chromatin morphological features were visualized and photographed using a fluorescence microscope. While control cells treated with $0.5 \% \mathrm{v} / \mathrm{v}$ DMSO have normal appearing nuclei (A and $\mathbf{E}$ ), cells treated with the apoptosis-inducing agents staurosporine (B), ALLnL (C), etoposide (D) and anti-Fas activating antibody (F) show extremely condensed and fragmented chromatin. Chromatin condensation and fragmentation caused by anti-Fas antibody were completely blocked by the pan-caspase inhibitor, Z-VAD-fmk at $100 \mu \mathrm{M}(\mathbf{G})$, while cells treated with Z-VAD-fmk alone had normal appearing chromatin (not shown). A peptide, Z-FA, that does not inhibit caspases did not prevent chromatin condensation in cells challenged with anti-Fas antibody $(\mathbf{H})$

We have previously demonstrated the loss of $\mathrm{uH} 2 \mathrm{~A}$ signal in anti-ubiquitin immunoblots of isolated chromatin is a consequence of $\mathrm{uH} 2 \mathrm{~A}$ deubiquitination rather than degradation of either the ubiquitin or the histone moiety. ${ }^{12}$
In addition, in Western blots, anti-ubiquitin antibodies from different commercial sources uniformly recognize $\mathrm{uH} 2 \mathrm{~A}$ in the chromatin fraction but not the clarified lysate fraction of cells (data not shown). Essentially identical declines in uH2A were observed in crude chromatin fractions, in purified chromatin extracts and in histones isolated from cells undergoing apoptosis. Finally, we examined the nucleosomal histone profile in sulfuric acid-extracts of cells undergoing apoptosis initiated by doxorubicin, etoposide or staurosporine. When analyzed on AUT-polyacrylamide gels stained with Coomassie blue dye, neither histone H2A nor the other four nucleosomal histones $(\mathrm{H} 1, \mathrm{H} 2 \mathrm{~B}, \mathrm{H} 3$ and $\mathrm{H} 4)$ were different in histone extracts from apoptotic cells compared to extracts from control cells (results not shown). These results support the interpretation that the decline in the $\mathrm{uH} 2 \mathrm{~A}$ signal in anti-ubiquitin immunoblots of chromatin preparations from apoptotic cells results solely from $\mathrm{uH} 2 \mathrm{~A}$ deubiquitination.

Differences in the time required for the initiation of chromatin condensation in cells treated with the various apoptosis-initiating agents provided an opportunity for us to evaluate the relationship between the ubiquitin status of nucleosomal histone H2A, PARP cleavage and chromatin condensation during the progression of apoptosis. Antiubiquitin immunoblots revealed that the apoptosis-inducing agents, doxorubicin, staurosporine, etoposide, anti-Fas antibody and ALLnL, all caused a progressive deubiquitination of $\mathrm{UH} 2 \mathrm{~A}$ in the chromatin fraction from cells (Figure $4 A-E)$ just before or coincident with chromatin condensation (Figure $1 \mathrm{~A}-\mathrm{E}$ ). In cells treated with staurosporine, etoposide or anti-Fas antibody, $\mathrm{uH} 2 \mathrm{~A}$ deubiquitination occurred subsequent to the initiation of caspase-dependent cleavage of PARP (Figure 4A-E). However, uH2A was slightly decreased prior to measurable PARP cleavage in cells treated with doxorubicin or ALLnL. The decline in $\mathrm{uH} 2 \mathrm{~A}$ within $1 \mathrm{~h}$ of $\mathrm{ALLnL}$ treatment was independent of morphological signs of apoptosis, although at longer incubation times, ALLnL eventually caused PARP cleavage, plasma membrane blebbing and chromatin condensation (Figures 1D, 2C and 4D). In response to doxorubicin treatment, $\mathrm{uH} 2 \mathrm{~A}$ was decreased within $2 \mathrm{~h}$, however, PARP cleavage was not detectable until $8 \mathrm{~h}$ of doxorubicin exposure (Figure 4A). It is unclear why uH2A deubiquitination and PARP cleavage did not coincide in cells treated with doxorubicin. Perhaps $\mathrm{UH} 2 \mathrm{~A}$ deubiquitination and PARP cleavage in doxorubicin-treated cells are dependent upon the activation of different pro-caspases.

\section{Caspase-3 activation during apoptosis}

We then measured procaspase-3 activation in lysates from cells undergoing apoptosis initiated by the five inducing agents. Following doxorubicin treatment, caspase-3 activity was not stimulated in Jurkat cells before $6-8 \mathrm{~h}$ of exposure, which coincided closely with the time of initiation of PARP cleavage (Figures $4 \mathrm{~A}$ and $5 \mathrm{~A}$ ). The observation that caspase-3 activation occurred subsequent to uH2A deubiquitination during doxorubicin-induced apoptosis suggests that $\mathrm{uH} 2 \mathrm{~A}$ deubiquitination was independent of caspase-3 activity. (Figure 4A). It is possible that PARP cleavage and 


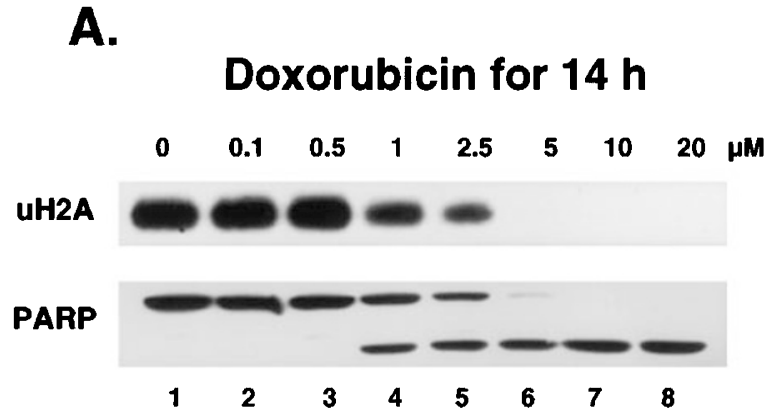

C.

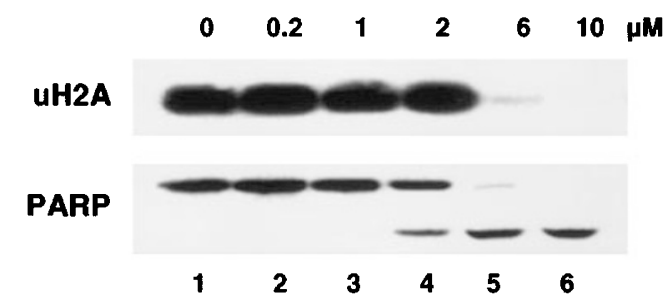

B.

\section{Staurosporine for $6 \mathrm{~h}$}

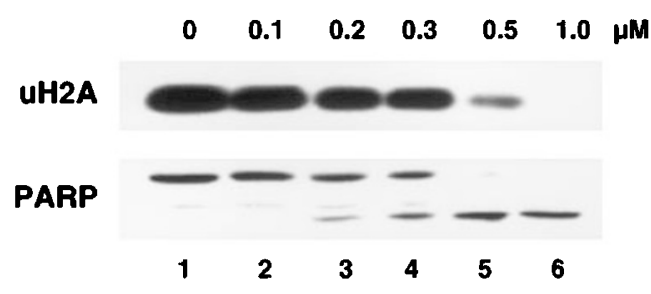

D.

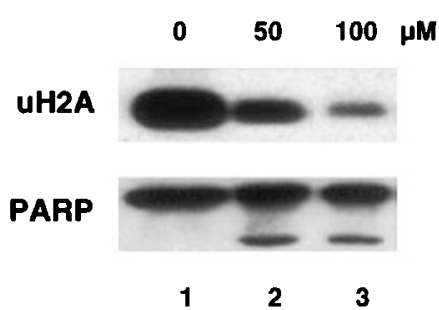

Figure 3 Concentration-dependent induction of PARP cleavage and deubiquitination of uH2A by various apoptogenic agents. Jurkat cells were treated with a range of concentrations of apoptosis-initiating agents at several fixed times based on pilot experiments, as indicated. After washing with ice-cold PBS, the cells were lysed into TNESV lysis buffer containing protease inhibitors and chromatin and clarified lysate fractions were isolated by centrifugation. Following SDSPAGE of chromatin $(20 \mu \mathrm{g})$ and clarified lysate $(100 \mu \mathrm{g})$ fractions, uH2A and PARP were determined by immunoblotting. uH2A was detected at $23 \mathrm{kDa}$ and intact PARP at $116 \mathrm{kDa}$, while the caspase-cleaved PARP fragment was $85 \mathrm{kDa}$. (A) doxorubicin for $14 \mathrm{~h}$, (B) staurosporine for $6 \mathrm{~h}$, (C) etoposide for $24 \mathrm{~h}$, and (D) ALLnL for $4 \mathrm{~h}$. Note the coincidence between the initiation of UH2A deubiquitination (upper panels) and caspase-dependent PARP cleavage to its fragment (lower panels). The numbers above the $\mathrm{uH} 2 \mathrm{~A}$ panels indicate the concentration of the apoptosis inducers, while the numbers below the PARP panels identify the lanes

$\mathrm{uH} 2 \mathrm{~A}$ deubiquitination respond to different caspases during doxorubicin-induced apoptosis, because further experiments with inhibitors (described below) suggest an interplay between $\mathrm{uH} 2 \mathrm{~A}$ deubiquitination and the activation of the caspase cascade. Although $\mathrm{uH} 2 \mathrm{~A}$ deubiquitination in ALLnL-treated cells was observed as rapidly as $2 \mathrm{~h}$ (Figure 4D), caspase-3 activation did not take place until $4 \mathrm{~h}$, a result consistent with the initiation of PARP cleavage after a $4 \mathrm{~h}$ ALLnL exposure (Figures 3D and 4D). An explanation for this apparent discrepancy in ALLnL-treated cells is that deubiquitination of $\mathrm{uH} 2 \mathrm{~A}$ was foremost a consequence of proteasome inhibition, as we have previously reported. ${ }^{12}$ The other apoptosis inhibitors: staurosporine, anti-Fas antibody (Figure 5A) and etoposide (Figure 5B), all strongly activated caspase-3 activity within a few hours. Thus, deubiquitination of $\mathrm{uH} 2 \mathrm{~A}$ clearly took place after caspase3 activation in cells treated with staurosporine, etoposide and anti-Fas antibody.

The pronounced biphasic caspase-3 activity following doxorubicin, ALLnL and etoposide treatments (Figure 5A,B) could be attributed to caspase- 3 inactivation caused by other proteases that were activated at the late stage of apoptosis. Alternatively, caspase-3 may have been degraded as a result of the ubiquitin ligase activity of IAP and XIAP, two activatable protein 'inhibitors of apoptosis', ${ }^{14}$ which have recently been shown to target caspases-3 and -7 for degradation. ${ }^{15}$

\section{Caspase inhibitor-blocked uH2A deubiquitination, PARP cleavage and chromatin condensation}

To determine whether $\mathrm{uH} 2 \mathrm{~A}$ deubiquitination in apoptosis was dependent upon procaspase activation, we pre-treated Jurkat cells for $1 \mathrm{~h}$ with the pan-caspase inhibitor, Z-VAD-fmk $(100 \mu \mathrm{M})$, then exposed cells to the panel of apoptosisinducing agents. In the absence of Z-VAD-fmk, ALLnL (Figure $6 \mathrm{~A}$ ), anti-Fas activating antibody (Figure 6B), etoposide (Figure 6C), staurosporine (Figure 6C) and doxorubicin (Figure 6D) all strongly promoted $\mathrm{uH} 2 \mathrm{~A}$ deubiquitination and extensive PARP cleavage. In cells pre-treated with Z-VADfmk for $1 \mathrm{~h}, \mathrm{uH} 2 \mathrm{~A}$ deubiquitination and PARP cleavage were essentially completely blocked (Figure 6A-D). The sole exception was ALLnL-treatment, where Z-VAD-fmk diminished PARP cleavage that occurred between 4 and $14 \mathrm{~h}$ of treatment, but only partially prevented the loss of $\mathrm{uH} 2 \mathrm{~A}$ (Figure 6A). One interpretation of this apparent anomaly is that ALLnL promoted $\mathrm{UH} 2 \mathrm{~A}$ deubiquitination by two mechanisms, only one of which was caspase dependent. The data are consistent with the idea that ALLnL caused $u H 2 A$ deubiquitination within $4 \mathrm{~h}$ was a consequence of preventing the proteasome from degrading ubiquitinated proteins. Proteasome inhibition causes ubiquitinated proteins to accumulate, consumes the cellular pool of free ubiquitin and initiates $\mathrm{uH} 2 \mathrm{~A}$ deubiquitination. ${ }^{12}$ During a longer exposure to ALLnL (14 h), as apoptosis ensued, the small amount of residual $\mathrm{uH} 2 \mathrm{~A}$ was 

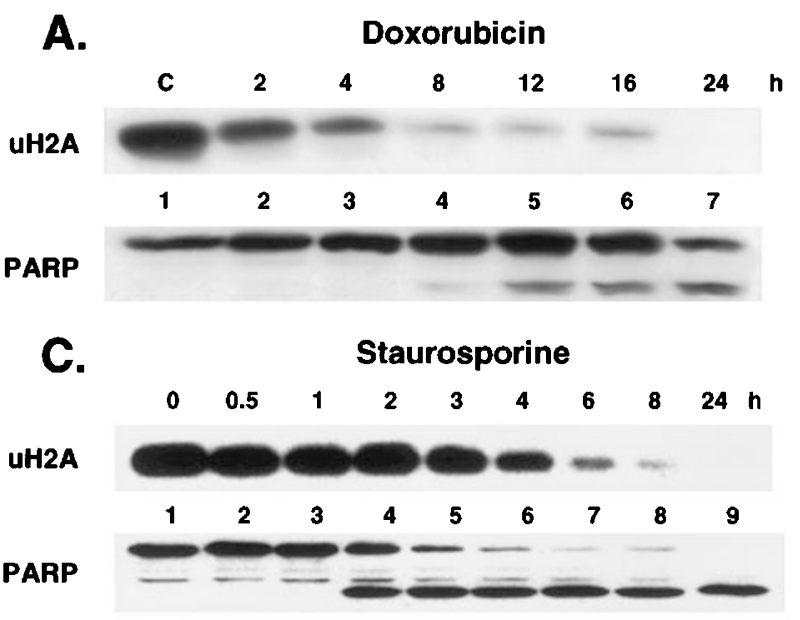

\section{B. Anti-Fas activating Ab}

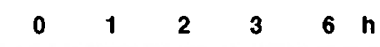

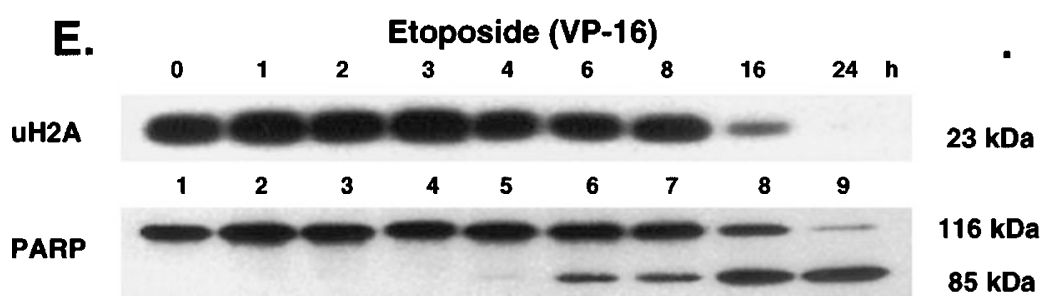

Figure 4 Time course of $\mathrm{uH} 2 \mathrm{~A}$ deubiquitination and PARP cleavage during apoptosis. Jurkat cells were treated with $5 \mu \mathrm{M}$ doxorubicin $(\mathbf{A}), 100 \mathrm{ng} / \mathrm{ml}$ anti-Fas activating antibody (B), $1.0 \mu \mathrm{M}$ staurosporine (C), $100 \mu \mathrm{M}$ ALLnL (D) or $10 \mu \mathrm{M}$ etoposide (E), at concentrations that initiated apoptosis within $\sim 12 \mathrm{~h}$. At various times during the progression of apoptosis, cells were lysed and $\mathrm{uH} 2 \mathrm{~A}(23 \mathrm{kDa})$ and PARP status were evaluated by immunoblotting. The numbers above the uH2A panels indicate the incubation time in hours, and the numbers between the $\mathrm{UH} 2 \mathrm{~A}$ and PARP immunoblot panels identify the lanes
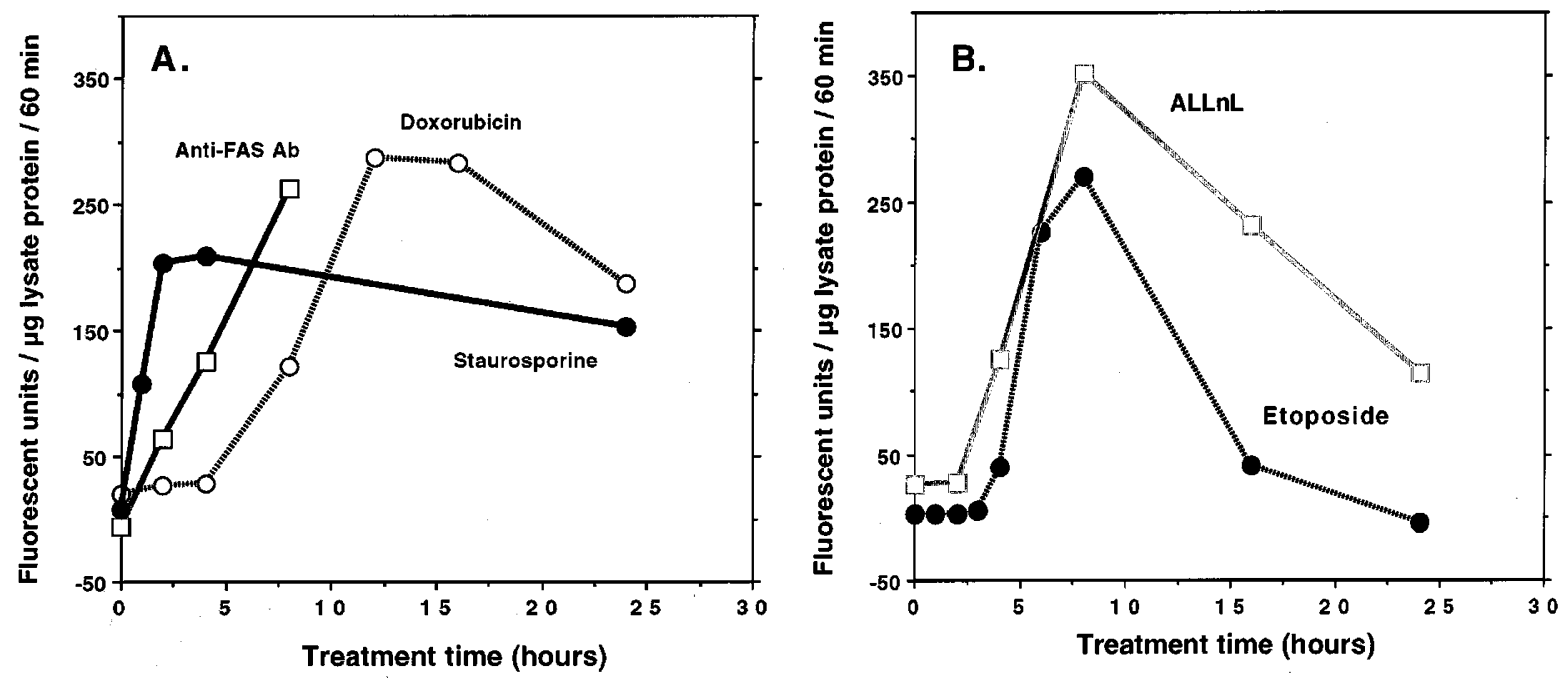

Figure 5 Caspase-3 activation in Jurkat cells treated with apoptogenic agents. Jurkat cells were treated with (A) $100 \mathrm{ng} / \mathrm{ml}$ anti-Fas antibody, $5 \mu \mathrm{M}$ doxorubicin or $1.0 \mu \mathrm{M}$ staurosporine, or (B) $20 \mu \mathrm{M}$ etoposide or $100 \mu \mathrm{M}$ ALLnL for various times, then lysed and the caspase-3 activity in the clarified lysate fraction (20 to $50 \mu \mathrm{g}$ of protein) was assayed at $37^{\circ} \mathrm{C}$ using the fluorogenic substrate, Ac-DEVD-AMC. Each of the apoptosis inducing agents greatly enhanced caspase-3 activity compared to caspase activity in DMSO-treated control cells, although the time to reach maximum caspase-3 activity varied considerably. Following doxorubicin, etoposide and ALLnL treatments, caspase-3 activity was sharply biphasic, with induction of maximal activity within $5-10 \mathrm{~h}$, followed by a sharp decline in activity

further depleted, and only this portion of the total uH2A loss was sensitive to caspase inhibition. In cells exposed to ZVAD-fmk alone, uH2A was unchanged and PARP cleavage was absent (Figure 6A, lane 6). Z-FA, a peptide analog that does not inhibit caspases, neither prevented anti-Fas antibody-initiated apoptosis nor inhibited deubiquitination of $\mathrm{uH} 2 \mathrm{~A}$ (Figure 6B, lanes 10-12). Taken together, these observations indicate that $\mathrm{uH} 2 \mathrm{~A}$ deubiquitination in cells 


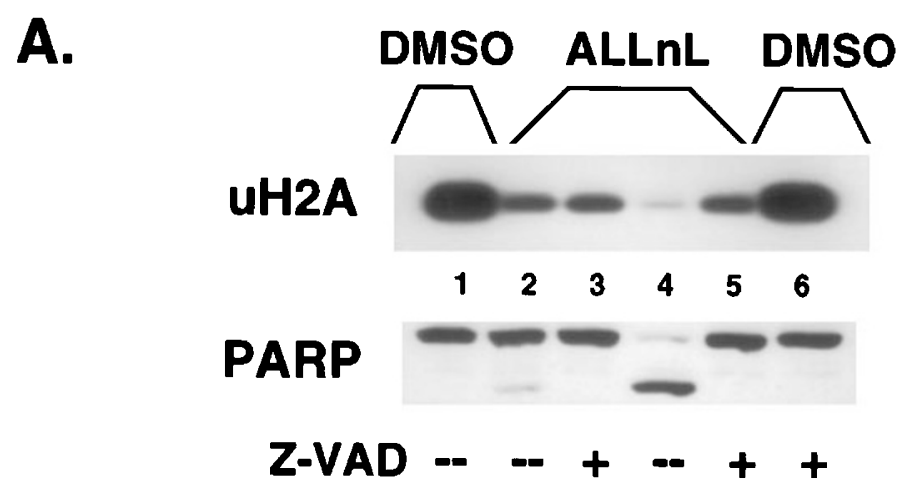

B.

Controls

Anti-FAS

Anti-FAS

Anti-FAS

\& Z-VAD

\& Z-FA

\section{uH2A}

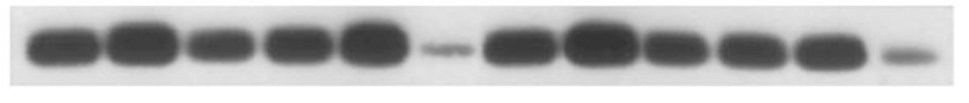

PARP

$\begin{array}{llllllllllll}1 & 2 & 3 & 4 & 5 & 6 & 7 & 8 & 9 & 10 & 11 & 12\end{array}$

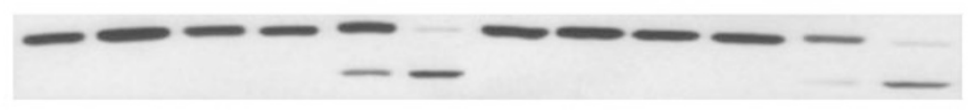

$\begin{array}{lllllllllllll}0 & 2 & 8 & 0 & 2 & 8 & 0 & 2 & 8 & 0 & 2 & 8 & h\end{array}$
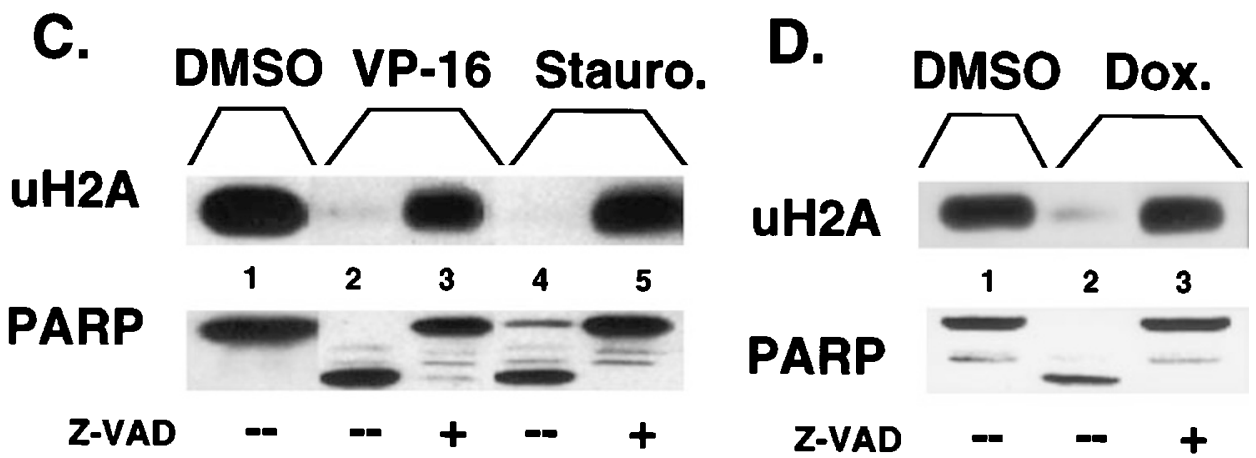

Figure 6 The pan-caspase inhibitor, Z-VAD-fmk, blocks PARP cleavage and diminishes uH2A deubiquitination in cells treated with apoptogenic agents. Jurkat cells were pre-treated with $100 \mu \mathrm{M} Z$-VAD-fmk for $1 \mathrm{~h}$, then exposed to apoptosis initiators. The levels of uH2A and PARP were determined by immunoblotting at selected times after apoptosis had been initiated, as determined by previous experiments and by the appearance of characteristic morphological changes. (A) $100 \mu \mathrm{M}$ ALLnL at $4 \mathrm{~h}$ (lane 2) decreased the level of uH2A without PARP cleavage, and Z-VAD-fmk had no effect on the loss of uH2A (lane 3). However, by $14 \mathrm{~h}$, when uH2A was nearly completely depleted (lane 4), PARP cleavage was appreciable (lane 4). In Z-VAD-fmk pre-treated cells, the progressive decline in uH2A between 4 and $14 \mathrm{~h}$ was attenuated and PARP cleavage occurring between $4 \mathrm{~h}$ and $14 \mathrm{~h}$ was completely blocked (lane 5 ). Neither uH2A nor PARP were altered by Z-VAD-fmk alone (lane 6). Deubiquitination of uH2A at the $4 \mathrm{~h}$ time point in cells treated with ALLnL was most likely an consequence of proteasome inhibition, ${ }^{12}$ but at $14 \mathrm{~h}$, when apoptosis had been initiated, the more robust deubiquitination of uH2A probably resulted from ALLnL-induced apoptosis. (B) Control cells were treated with $0.5 \%$ DMSO (lanes $1-3$ ), and $100 \mathrm{ng} / \mathrm{ml}$ anti-FAS activating antibody was added to control Jurkat cells for 2 and $8 \mathrm{~h}$ (lanes $4-6$ ) and to cells pretreated for $1 \mathrm{~h}$ with $100 \mu \mathrm{M}$ Z-VAD-fmk (lanes 7-9) or $100 \mu \mathrm{M}$ Z-FA (lanes 10-12). PARP cleavage directly coincided with deubiquitination of uH2A. Z-VAD-fmk, but not Z-FA, prevented both PARP cleavage and uH2A deubiquitination. ( $\mathbf{C}$ and $\mathbf{D}$ ) The immunoblots reveal that the extensive deubiquitination of uH2A and PARP cleavage caused by etoposide- (VP-16), staurosporine- and doxorubicin (Dox)-induced apoptosis (measured at 24, 6 and $14 \mathrm{~h}$, respectively) were completely blocked by $100 \mu \mathrm{M}$ Z-VAD-fmk pretreatment (C, lanes 3 and 5 ; $\mathbf{D}$, lane 3 ). (Note that $\mathbf{C}$ is a composite)

undergoing apoptosis was dependent upon activation of the caspase cascade. Notably, Z-VAD-fmk prevented deubiquitination of $\mathrm{uH} 2 \mathrm{~A}$ in doxorubicin-treated cells (Figure 6D), even though we previously observed that $\mathrm{uH} 2 \mathrm{~A}$ deubiquitination was initiated before PARP cleavage in cells treated with this drug (Figure 4A). uH2A deubiquitination in doxorubicin- induced apoptosis may be dependent upon an unidentified Z-VAD-fmk-sensitive caspase that does not target PARP as a substrate.

When chromatin condensation was examined in DAPIstained cells by fluorescence microscopy, we observed extensive chromatin condensation and chromatin fragmen- 
tation in cells treated with $100 \mathrm{ng} / \mathrm{ml}$ anti-Fas antibody for $8 \mathrm{~h}$ (Figure 2F), when compared to chromatin from untreated cells (Figure 2E). Chromatin condensation induced by anti-Fas antibody was completely prevented by a $1 \mathrm{~h}$ pretreatment with $100 \mu \mathrm{M}$ Z-VAD-fmk (Figure 2G), verifying the caspase-dependency of anti-Fas-induced chromatin condensation. In contrast, in cells pretreated with the inactive $100 \mu \mathrm{M}$ Z-FA peptide then challenged with anti-Fas antibody, chromatin condensation and fragmentation were indistinguishable from that caused by anti-Fas antibody alone (Figure $2 \mathrm{H}$ ). Thus, the caspase inhibitor, ZVAD-fmk, effectively blocked both chromatin condensation and $\mathrm{uH} 2 \mathrm{~A}$ deubiquitination in cells undergoing apoptosis induced by anti-Fas activating antibody.

\section{Bcl-xL over-expression blocks apoptosis, chromatin condensation and deubiquitination of uH2A}

$\mathrm{Bcl}-\mathrm{xL}$, an anti-apoptotic member of the $\mathrm{Bcl}-2$ protein family of proteins, prevents apoptosis in a number of model systems, ostensibly by preventing the release of cytochrome $c$ from mitochondria. ${ }^{16-18}$ We used stably-transfected, Bcl-xL protein-expressing Jurkat cells to test whether $\mathrm{Bcl}-\mathrm{xL}$ was capable of preventing deubiquitination of $\mathrm{uH} 2 \mathrm{~A}$ in cells challenged with apoptogenic agents. Empty vector-transfected (null) cells were used as controls. When the control cells were exposed to apoptosis-inducing agents, both $\mathrm{uH} 2 \mathrm{~A}$ deubiquitination and extensive PARP cleavage occurred, however, in Bcl-xL expressing Jurkat cells, deubiquitination of $\mathrm{uH} 2 \mathrm{~A}$ and PARP cleavage were strongly attenuated (Figure $7 A-C)$. In addition, Bcl-xL expressing cells exposed to apoptosis-causing agents exhibited little or no plasma membrane blebbing or chromatin condensation (results not shown). Because $\mathrm{Bcl}-\mathrm{xL}$ is thought to inhibit apoptosis by blocking the release of cytochrome $c$ from mitochondria and preventing activation of the caspase cascade, ${ }^{16,19}$ these observations support the hypothesis that $\mathrm{uH} 2 \mathrm{~A}$ deubiquitination is a caspase-dependent feature of apoptosis.

\section{Accumulation of ubiquitinated proteins and depletion of unconjugated ubiquitin during apoptosis}

Ubiquitinated proteins are known to accumulate in cells undergoing apoptosis. ${ }^{20,21}$ We asked whether ubiquitinated high molecular weight proteins were increased when Jurkat cells were induced to undergo apoptosis by the agents used in this study. Abundant ubiquitinated proteins were easily detected at the top of anti-ubiquitin immunoblots of lysates from cells treated with doxorubicin, etoposide or staurosporine (Figure $8 A-D$ ). Although we have not identified these apparently extensively ubiquitinated proteins, it is likely that at least some were targeted for ubiquitination because they became misfolded after being cleaved by caspases. In the case of ALLnL, proteasome inhibition was most likely responsible for stabilizing ubiquitinated proteins, however, at the $24 \mathrm{~h}$ time point, at least some ubiquitinated proteins may have accumulated as a consequence of ALLnL-induced apoptosis, which was fulminant by this time.

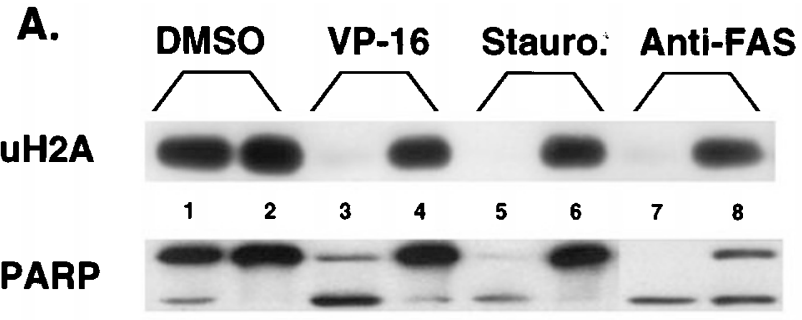

Ctr Bcl-xL Ctr Bcl-xL Crt Bcl-xL Ctr Bcl-xL

B.

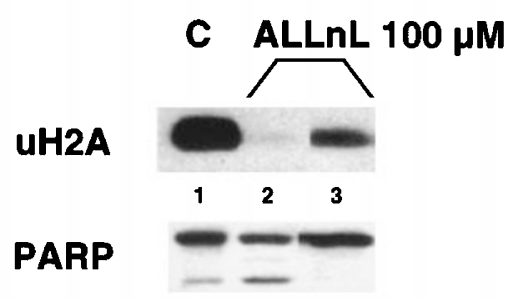

Bcl-xL Ctr BCl-xL

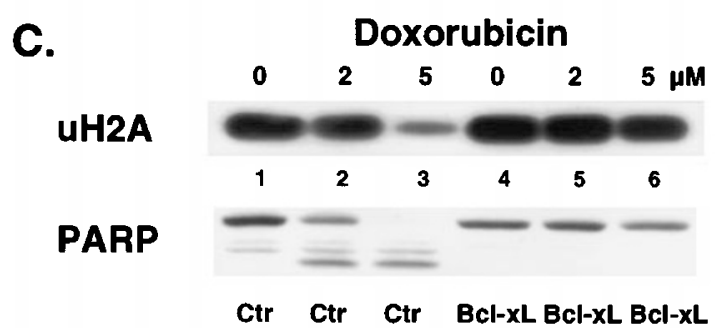

Figure 7 Deubiquitination of $\mathrm{UH} 2 \mathrm{~A}$ and PARP cleavage in stably-transfected, Bcl-xL-over-expressing Jurkat cells. Empty vector control Jurkat cells (Ctr) and $\mathrm{Bcl}-\mathrm{xL}$-transfected Jurkat cells $(\mathrm{Bcl}-\mathrm{xL})$ were exposed to apoptosisinitiating agents, and $\mathrm{uH} 2 \mathrm{~A}$ and PARP were determined by immunoblotting aliquots of chromatin and lysate fractions, respectively. In the empty vectortransfected cells, following $20 \mu \mathrm{M}$ etoposide (VP-16) for $24 \mathrm{~h}, 0.6 \mu \mathrm{M}$ staurosporine for $6 \mathrm{~h}$ or $100 \mathrm{ng} / \mathrm{ml}$ anti-FAS antibody for $6 \mathrm{~h}, \mathrm{uH} 2 \mathrm{~A}$ was essentially completely deubiquitinated and PARP was extensively cleaved (A). In contrast, in fractions from Bcl-xL-over-expressing cells, uH2A deubiquitination and PARP cleavage were greatly attenuated. $\mathrm{Bcl}-\mathrm{xL}$ completely blocked PARP cleavage in cells treated with $100 \mu \mathrm{M} \mathrm{ALLnL}$ for $6 \mathrm{~h}$, although $\mathrm{Bcl}-\mathrm{xL}$ over-expression only partially prevented deubiquitination of $\mathrm{uH} 2 \mathrm{~A}$ (B). Shown in (C), empty vector (Ctr) and Bcl-xL over-expressing cells $(\mathrm{Bcl}-\mathrm{xL})$ were treated with doxorubicin at 2 and $5 \mu \mathrm{M}$ for $14 \mathrm{~h}$. In control cells, both uH2A and full length PARP levels declined after cells were exposed to $5 \mu \mathrm{M}$ doxorubicin, but the $\mathrm{Bcl}-\mathrm{xL}$ over-expressing cells were refractory to doxorubicin-induced apoptosis and both $\mathrm{UH} 2 \mathrm{~A}$ deubiquitination and PARP cleavage were completely prevented. Each of the apoptosis-initiating treatments caused plasma membrane blebbing and chromatin condensation in the empty vector-Jurkat cells, but in cells over-expressing Bcl-xL, both of these morphological changes were greatly attenuated (results not shown)

Ubiquitinated high molecular weight proteins were also prominent in the isolated chromatin fraction of apoptotic cells (data not shown). In cells treated with the caspase inhibitor, Z-VAD-fmk, or in cells over-expressing Bcl-xL antiapoptotic protein, we did not observe any accumulation of high molecular weight ubiquitinated proteins when cells were challenged with apoptosis-inducing agents (data not shown).

We have previously reported that noxious chemicals and heat shock cause deubiquitination of $\mathrm{uH} 2 \mathrm{~A}$ and deplete the 
A.

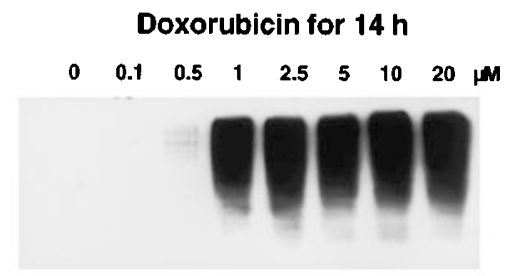

B.

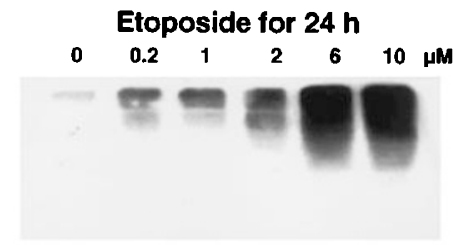

c.

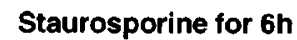

$\begin{array}{lllllll}0 & 0.1 & 0.2 & 0.3 & 0.5 & 1.0 & \mu M\end{array}$

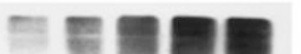

D.

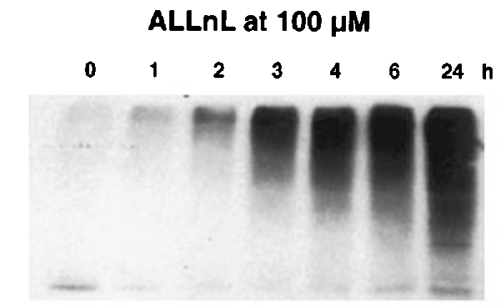

E. Unconjugated ubiquitin

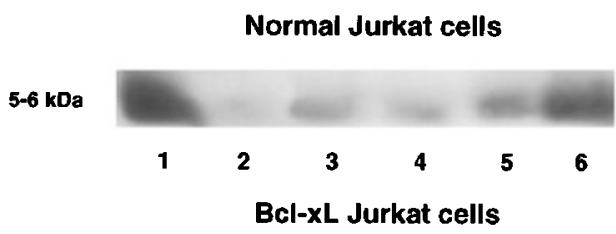

5-6 kDa

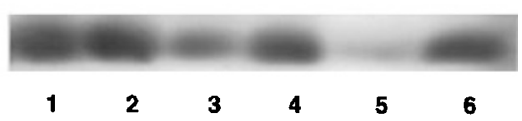

Figure 8 Apoptogenic agents cause accumulation of high molecular weight proteins and depletion of free ubiquitin. Jurkat cells were treated with doxorubicin (A), etoposide (B), staurosporine (C) or ALLnL (D), at the indicated times and concentrations, and poly-ubiquitinated proteins in the range of 200 to $500 \mathrm{kDa}$ near the top of the membranes were detected by anti-ubiquitin immunoblotting. Although little or no high molecular weight ubiquitinated proteins were detected in lysates from control cells, lysates from cells undergoing apoptosis contained abundant ubiquitinated proteins which increased as apoptosis progressed. The presence of these ubiquitinated proteins indicates that ubiquitin activating and conjugating enzymes retained activity during apoptosis. For both normal and Bcl-xL-over-expressing cells in (E) (top and bottom panels) the treatments were: $0.5 \%$ DMSO treated control cells (lane 1), $10 \mu \mathrm{M}$ doxorubicin (lane 2), $20 \mu \mathrm{M}$ etoposide (lane 3), $1 \mu \mathrm{M}$ staurosporine (lane 4), $100 \mu \mathrm{M}$ ALLnL (lane 5) and $100 \mathrm{ng} / \mathrm{ml}$ anti-Fas antibody (lane 6). Each of the apoptosis-inducing agents markedly depleted unconjugated ubiquitin in normal Jurkat cells (E, top panel, lanes 2-6), while Bcl-xL over-expressing Jurkat cells had little or no depletion of unconjugated ubiquitin when exposed to apoptogenic agents (E, bottom panel, lanes 2-4 and 6), except for ALLnL (E, bottom panel, lane 5)

cytoplasmic pool of unconjugated ubiquitin. ${ }^{12,13}$ In the present investigation, each of the apoptosis-inducing agents depressed the level of unconjugated ubiquitin (Figure 8E, top, lanes 1-5), with the exception of antiFas antibody (Figure 8E, top, lane 6). In cells undergoing apoptosis initiated by doxorubicin, etoposide, staurosporine or ALLnL, ubiquitinated proteins accumulated, unconjugated ubiquitin was depleted and ubiquitin was enzymatically cleaved from nucleosomal $\mathrm{uH} 2 \mathrm{~A}$. Depletion of free ubiquitin below a threshold level during apoptosis might stimulate deubiquitination of $\mathrm{uH} 2 \mathrm{~A}$ in an attempt by the cell to supply ubiquitin to be used to target misfolded or otherwise damaged proteins for proteasomal degradation.

In Jurkat cells over-expressing $\mathrm{Bcl}-\mathrm{xL}$ protein, apoptosis was prevented and the loss of free ubiquitin was likewise blunted following exposure to apoptosis inducers, with the exception of ALLnL (Figure 8E, bottom panel). Since depletion of unconjugated ubiquitin in ALLnL-treated cells was probably the consequence of proteasome inhibition and stabilization of ubiquitinated proteins, ${ }^{12} \mathrm{Bcl}-\mathrm{xL}$ would not be expected to prevent ubiquitin consumption.

\section{Deubiquitination of uH2A during apoptosis in other cells}

To ensure that $\mathrm{UH} 2 \mathrm{~A}$ deubiquitination during apoptosis was not a phenomenon peculiar to Jurkat cells, we measured $\mathrm{uH} 2 \mathrm{~A}$ levels in chromatin isolated from A2780/CP70 ovarian,
MCF-7 and SKBr-3 breast and A431 vulva carcinoma cells induced to undergo apoptosis (Figure 9A-D). A2780/CP70 cisplatin-resistant ovarian carcinoma cells, in particular, were significantly more resistant to each of the apoptosis inducing agents than Jurkat cells. Consequently higher concentrations of apoptosis inducers and longer exposures were required to initiate apoptosis and deubiquitinate $\mathrm{uH} 2 \mathrm{~A}$ in these cells (Figure 9A). In each of the cell lines we have examined, uH2A deubiquitination occurred concurrently with chromatin condensation and PARP cleavage, upholding an association of $\mathrm{uH} 2 \mathrm{~A}$ deubiquitination with the induction of apoptosis (results not shown).

\section{Deubiquitination of uH2A in cells transfected with a deubiquitinating enzyme-encoded gene}

We asked whether $\mathrm{UH} 2 \mathrm{~A}$ deubiquitination, as an isolated biochemical event, could trigger apoptosis in the absence of any chemical initiator of apoptosis. To address this question, we transiently transfected 293 cells with a plasmid vector containing the coding sequence for Ubp-M, a human deubiquitinating enzyme that can cleave ubiquitin from uH2A in vitro. ${ }^{9}$ Cells were also transfected with a vector expressing a mutation-inactivated Ubp-M deubiquitinating enzyme (mutant Ubp-M). The mutant Ubp-M strongly associates with mitotic chromosomes and blocks cell division, presumably by interfering with cell cycle-induced chromosome condensation. ${ }^{9}$ Both the active and the mutant 
A. A2780 CP-70 ovarian carcinoma cells

Staurosporine for $18 \mathrm{~h}$

uH2A

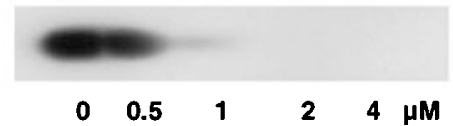

Etoposide for $72 \mathrm{~h}$

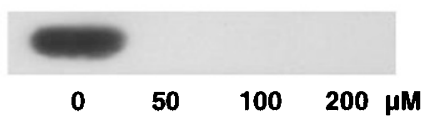

Doxorubicin for $18 \mathrm{~h}$

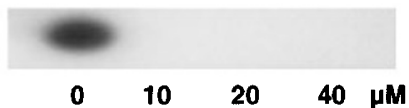

ALLnL at $100 \mu \mathrm{M}$

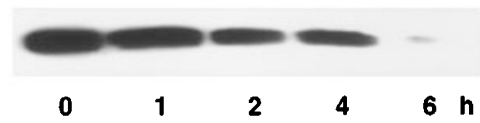

B. MCF- 7 breast carcinoma cells

Doxorubicin at $10 \mu \mathrm{M}$

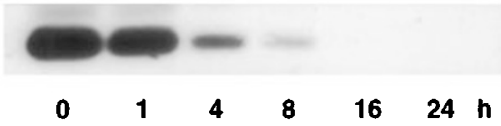

C. A431 vulva carcinoma cells

Doxorubicin at $5 \mu \mathrm{M}$

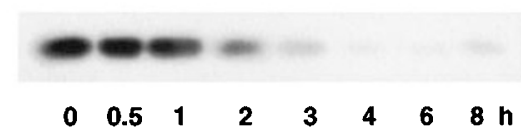

D. SKBr-3 breast carcinoma cells

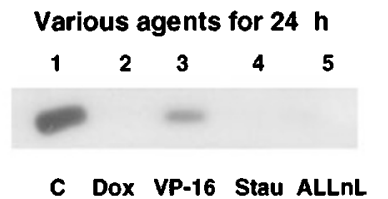

Figure 9 Apoptogenic agents promote deubiquitination of $\mathrm{uH} 2 \mathrm{~A}$ in human carcinoma cell lines. (A) To determine that deubiquitination of uH2A was not a biochemical modification that was unique to Jurkat cells undergoing apoptosis, we treated A2780/CP-70 human ovarian carcinoma cells with various concentrations of staurosporine for $18 \mathrm{~h}$, etoposide for $72 \mathrm{~h}$, doxorubicin for $18 \mathrm{~h}$ and $100 \mu \mathrm{M} \mathrm{ALLnL}$ for various times. In general, although A2780/CP-70 cells were relatively much more resistant to apoptosis caused by these agents than Jurkat cells, in all cases, uH2A eventually became deubiquitinated. Although not shown, PARP was cleaved to its $85 \mathrm{kDa}$ fragment in A2780/CP-70 cells by each of the treatments. Doxorubicin also decreased the uH2A level in MCF-7 (B), A431 (C) and SKBr-3 carcinoma cells (panel D, lane 2, labelled Dox). Also shown in (D) the loss of uH2A in SKBr-3 cells undergoing apoptosis initiated by $20 \mu \mathrm{M}$ etoposide (VP16) (lane 3), $1.0 \mu \mathrm{M}$ staurosporine (lane 4) and $100 \mu \mathrm{M} \mathrm{ALLnL}$ (lane 5) at $24 \mathrm{~h}$. Control cells (C) were exposed to $0.5 \%$ DMSO

deubiquitinating enzymes were expressed as GFP fusion proteins.

Within $48 \mathrm{~h}$ of transfecting cells with the active Ubp-M deubiquitinating enzyme, the level of $\mathrm{uH} 2 \mathrm{~A}$ was decreased by approximately $75 \%$ (Figure 10A, lane 2), while the uH2A content was unchanged or was slightly increased in cells transfected with the mutated Ubp-M (Figure 10A, lane 3). When examined by fluorescence microscopy, approximately $70 \%$ of cells transfected with the active and mutant Ubp-M fusion proteins expressed GFP (not shown). Furthermore, anti-GFP immunoblots revealed that both Ubp-M-GFP fusion proteins were expressed $48 \mathrm{~h}$ after transfection (Figure 10B, lanes 2 and 3). Both active and mutated enzymes were found in cell lysates and in the isolated chromatin fraction, where the mutant Ubp-M was consistently more abundant than the active Ubp-M enzyme (Figure 10D). While cells expressing the active Ubp-M fusion protein had significantly less uH2A (Figure 10A), there was essentially no PARP cleavage (Figure 9C). Likewise, procaspase-3 was not activated in cells transfected with either the active or mutant Ubp-M (data not shown). We did not observe morphological changes indicative of apoptosis within $72 \mathrm{~h}$ of tranfecting cells with expression vectors encoding either the active or mutated Ubp-M, and there was no increase in high molecular weight ubiquitinated proteins on anti-ubiquitin immunoblots of either chromatin or lysate fractions. In separate experi- ments, we observed that PARP was cleaved in cells expressing the Ubp-M-GFP fusion proteins during doxorubicin-induced apoptosis, which indicates that over-expression of the active and mutant Ubp-M proteins did not interfere with the cleavage of PARP by caspases (results not shown).

To address whether cell cycle arrest might play a role in $\mathrm{uH} 2 \mathrm{~A}$ deubiquitination in cells transfected with either the active or mutated Ubp-M, we exposed cells to serum withdrawal by culturing them in $0.1 \%$ FBS-containing medium for several days. UH2A levels were unaltered by 2 days of serum withdrawal, although by this time the cells were no longer adherent and growth was inhibited by nearly $50 \%$. After 3 days of serum starvation, however, clear signs of apoptosis (blebbing and nuclear condensation) were observed in approximately $20 \%$ of cells and $\mathrm{uH} 2 \mathrm{~A}$ was decreased by $\sim 40 \%$ (results not shown). These observations make it unlikely that $\mathrm{uH} 2 \mathrm{~A}$ was depleted as a consequence of cell cycle inhibition. Instead, deubiquitination of $\mathrm{uH} 2 \mathrm{~A}$ in cells experiencing serum withdrawal correlated with the induction of apoptosis.

The results of these experiments with the active and mutant Ubp-M deubiquitinating enzymes argue that deubiquitination of $\mathrm{uH} 2 \mathrm{~A}$, as a single event, is insufficient to initiate apoptosis, although $\mathrm{uH} 2 \mathrm{~A}$ deubiquitination may play a role in the progression of apoptosis once caspases have been activated. 
A.

\section{Anti-ubiquitin immunoblot}

Ubp-M transfected

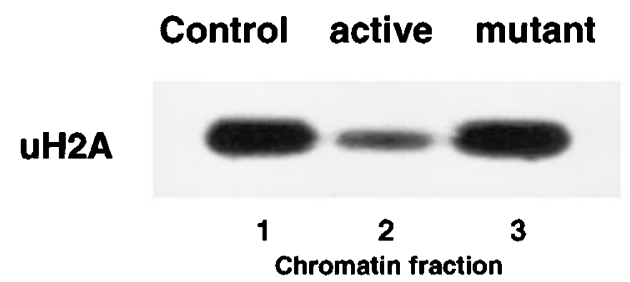

C.

\section{Anti-PARP immunoblot}

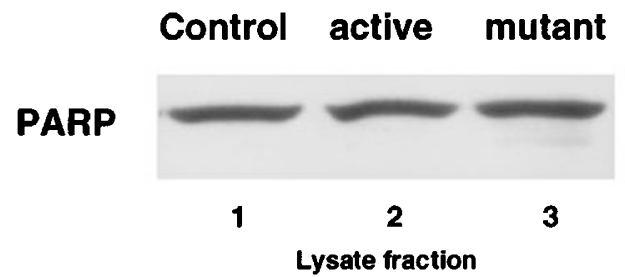

B.

\section{GFP immunoblot}

\section{Ubp-M transfected}
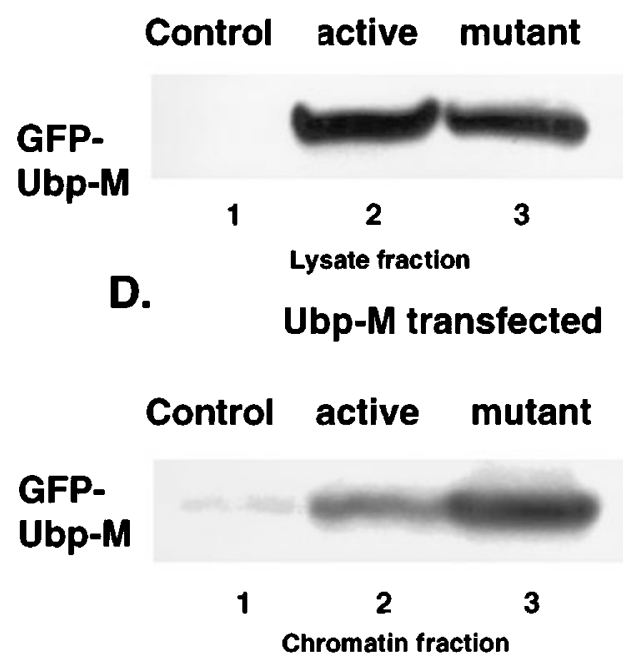

Figure 10 Transfection of 293 cells with a gene encoding a deubiquitinating enzyme depletes uH2A but does not initiate PARP cleavage. Human 293 kidney cells were transfected with plasmids encoding the Ubp-M deubiquitinating enzyme or an inactive, mutated Ubp-M enzyme. Both proteins were expressed as GFP fusions. (A) Anti-ubiquitin immunoblots of chromatin fractions isolated from mock-transfected (lipofectamine reagents only) cells (lane 1), cells expressing the active deubiquitinating enzyme (lane 2 ) and cells expressing the mutated, inactive enzyme (lane 3 ) $48 \mathrm{~h}$ post-transfection. Although compared to control cells, the $\mathrm{uH} 2 \mathrm{~A}$ level was significantly decreased in cells expressing the active Ubp-M deubiquitinating enzyme, uH2A was unchanged in cells expressing the mutated Ubp-M enzyme. Lysate (B) and chromatin (D) fractions were probed for expression of the GFP-Ubp-M fusion protein using an anti-GFP antibody. Although active and mutated GFP-fusion protein levels were similar in the lysate fraction $48 \mathrm{~h}$ after transfections (panel B, lanes 2 and 3 ), significantly more of the mutated Ubp-M-GFP fusion protein was found associated with chromatin than the active Ubp-M-GFP fusion transcript (D, lanes 2 and 3 ). (C) shows a PARP immunoblot of lysate fraction from mock-transfected cells (lane 1), transfectants expressing the active Ubp-M deubiquitinating enzyme (lane 2) and cells expressing the mutated Ubp-M enzyme (lane 3)

\section{Discussion}

It is evident from the data presented here that deubiquitination of $\mathrm{uH} 2 \mathrm{~A}$ takes place in a variety of cells undergoing apoptosis initiated by diverse-acting apoptosis-inducers. These results confirm and extend observations by Marushige et al. ${ }^{10}$ and Tanimoto et al., ${ }^{11}$ who reported $\mathrm{uH} 2 \mathrm{~A}$ deubiquitination in cells undergoing apoptosis induced by TGF- $\beta$ or by proteasome inhibitors. Independent of the mechanism of apoptosis induction, the characteristic apoptotic morphological changes of plasma membrane blebbing and chromatin condensation, procaspase-3 activation, caspase-dependent PARP cleavage and nucleosomal $\mathrm{uH} 2 \mathrm{~A}$ depletion occurred nearly concurrently in Jurkat and other cells exposed to apoptosis-inducing agents. For example, exposing Jurkat cells to anti-Fas antibody or staurosporin rapidly caused plasma membrane blebbing, chromatin condensation, procaspase-3 activation, PARP cleavage and deubiquitination of $\mathrm{uH} 2 \mathrm{~A}$ within hours; while in contrast, with A2780/CP70 ovarian tumor cells, cellular morphological changes, PARP cleavage and $\mathrm{uH} 2 \mathrm{~A}$ deubiquitination required several days exposure when etoposide was the apoptosis-initiator. Furthermore, uH2A deubiquitination did not occur when apoptosis was inhibited in cells exposed to the various apoptogenic agents, with the exception of the proteasome inhibitor, ALLnL.
What signal initiates the enzymatic deubiquitination of nucleosomal $\mathrm{uH} 2 \mathrm{~A}$ during apoptosis? Following exposure to most of the apoptosis initiators, $\mathrm{UH} 2 \mathrm{~A}$ deubiquitination was preceded by or coincided with the initiation of PARP cleavage, suggesting that $\mathrm{uH} 2 \mathrm{~A}$ deubiquitination, like PARP cleavage, may be a caspase-mediated event. In support of this hypothesis, blocking apoptosis by inhibiting caspases with Z-VAD-fmk, or preventing caspase cascade activation by over-expressing anti-apoptotic Bcl-xL protein, prevented both $\mathrm{UH} 2 \mathrm{~A}$ deubiquitination and PARP cleavage after cells were challenged with potent apoptosis inducers. With the exception of cells exposed to ALLnL at early times before apoptosis could be detected, deubiquitination of $\mathrm{uH} 2 \mathrm{~A}$ did not take place in the absence of procaspase activation.

Several possible mechanisms linking caspases with uH2A deubiquitination are consistent with our results presented here. In the most straightforward of these, one or more caspases might directly activate latent deubiquitinating lyases and/or isopeptidases that cleave ubiquitin from nucleosomal $\mathrm{uH} 2 \mathrm{~A}$. Activation of a histone-directed deubiquitinating enzyme by caspases, however, would require a high degree of specificity for monoubiquitinated histone $\mathrm{H} 2 \mathrm{~A}$, because other cytosolic and chromatinassociated ubiquitinated proteins accumulate, rather than decline, during apoptosis ${ }^{20}$ (and this report). The observation that many, if not most, ubiquitinated proteins are not 
susceptible to enzymatic deubiquitination during apoptosis highlights $\mathrm{uH} 2 \mathrm{~A}$ deubiquitination as a novel apoptotic event. Although in vitro, several enzymes have been shown to mono-ubiquitinate histone $\mathrm{H} 2 \mathrm{~A},{ }^{22,23}$ and several classes of enzymes catalyze deubiquitination of $\mathrm{uH} 2 \mathrm{~A},{ }^{24,25}$ the enzymatic regulation of the dynamic equilibrium between ubiquitinated and deubiquitinated $\mathrm{H} 2 \mathrm{~A}$ within chromatin in vivo has not yet been elucidated. Interestingly, a ubiquitin-cleaving isopeptidase exhibiting a high affinity for histone $\mathrm{H} 2 \mathrm{~A}$ has been reported to associate with mitotic chromatin at 10 -fold higher levels than during interphase, ${ }^{26,27}$ but whether this particular deubiquitinating enzyme targets $\mathrm{uH} 2 \mathrm{~A}$ during apoptosis is not known. The possible regulation of deubiquitinating enzymes by caspases has not been previously investigated.

It is feasible that $\mathrm{uH} 2 \mathrm{~A}$ deubiquitination during apoptosis results from the failure of cells to maintain the dynamic equilibrium of $\mathrm{H} 2 \mathrm{~A}$ ubiquitination as a consequence of caspase-dependent inactivation of a histone H2A-specific, ubiquitin-conjugating E2 or E3 enzyme. The ubiquitinprotein ligase, Nedd4, is cleaved by caspases that are activated during apoptosis, ${ }^{28}$ although it is unknown whether this particular ubiquitin ligase can ubiquitinate nucleosomal histone H2A. Whether any of the myriad of other E2 and E3 ubiquitinating enzymes are substrates for caspases is also unknown.

A third possibility relates to the observation that activated caspases cleave many proteins during apoptosis. ${ }^{29-31}$ It is likely at least some caspase-cleaved proteins become misfolded and are targeted by ubiquitin conjugating enzymes for proteasomal degradation. However, the massive accumulation of ubiquitinated proteins in cells undergoing apoptosis ${ }^{20,21}$ raises the possibility that the sheer abundance of misfolded, ubiquitinated proteins overwhelms the ability of the proteasome to degrade them. During apoptosis, aggregation-prone proteins might collect into what amounts to potentially dangerous, insoluble, ubiquitinated protein sludge. Indeed, recent evidence indicates that misfolded, detergent-insoluble, heavily ubiquitinated proteins accumulate in distinct pericentriolar structures called 'aggresomes'. ${ }^{32,33}$ If this process consumes the cell's supply of unconjugated ubiquitin faster than it is synthesized, then depletion of ubiquitin, especially in the nucleus, might tilt the balance of the histone $\mathrm{H} 2 \mathrm{~A}$ ubiquitination/deubiquitination dynamic equilibrium toward deubiquitination. Supporting this view, in cells undergoing apoptosis, there was a substantial increase in high molecular weight ubiquitinated proteins that closely coincided with depletion of unconjugated ubiquitin and loss of $\mathrm{uH} 2 \mathrm{~A}$. Also consistent with this hypothesis, proteasome inhibitors and other noxious treatments, including heatshock, promote the accumulation of ubiquitinated proteins, deplete cellular unconjugated ubiquitin pools and cause $\mathrm{uH} 2 \mathrm{~A}$ deubiquitination. ${ }^{12}$ We believe this multi-step process centering on the consumption of unconjugated ubiquitin promoted by caspase-dependent protein cleavage is the most likely mechanism responsible for the dramatic loss of nucleosomal $\mathrm{uH} 2 \mathrm{~A}$ during apoptosis.

At this time, we cannot rule-out the possibility that deubiquitination of $\mathrm{uH} 2 \mathrm{~A}$ occurs subsequent to caspase- activated, nuclease-mediated DNA strand breaks. Endonuclease-dependent DNA strand breaks in chromatin of apoptotic cells induce hyper-phosphorylation of the histone H2AX subtype, presumably by activating a histone kinase that recognizes DNA double strand breaks. ${ }^{34}$ By analogy, one or more deubiquitinating enzymes, perhaps as components of DNA damage recognition and repair complexes, might be recruited to endonuclease-severed DNA within apoptotic chromatin to catalyze $\mathrm{uH} 2 \mathrm{~A}$ deubiquitination. Recently, the DNA nucleotide-excision repair protein Rad23 was found to suppress ubiquitination of histone $\mathrm{H} 2 \mathrm{~B}$ in vitro, ${ }^{35}$ although the mechanism of this Rad23 function remains to be determined, its ability to influence histone ubiquitination is notable.

While it is known that $\mathrm{uH} 2 \mathrm{~A}$ deubiquitination occurs naturally during mitosis as cells progress from prophase to metaphase, ${ }^{26}$ we do not believe the disappearance of $\mathrm{uH} 2 \mathrm{~A}$ during apoptosis is the indirect consequence cell cycle blockade. Arguing against this possibility, neither doxorubicin nor etoposide arrests cells during metaphase, when ubiquitin is cleaved from $\mathrm{uH} 2 \mathrm{~A}$ and chromatin condenses into chromosomes. Instead, doxorubicin-treated cells usually progress through $\mathrm{G} 1$ and $S$ phases, then die in G2. Likewise, etoposide predominantly arrests cells in the G2 phase of the cycle. Because these drugs prevent cells from progressing through mitosis, they block metaphase chromosome condensation. This would be expected to stabilize, rather than to promote, $\mathrm{uH} 2 \mathrm{~A}$ deubiquitination. Additionally, when we withdrew cells from serum, which causes $\mathrm{G} 1$ arrest, the ubiquitin status of $\mathrm{uH} 2 \mathrm{~A}$ remained stable until $3 d$ of serum starvation, a time when morphological signs of apoptosis were clearly apparent. Finally, transient expression of a mutated Ubp-M deubiquitinating enzyme, in contrast to the enzymatically active Ubp-M protein, has been shown to block cell cycle progression. ${ }^{9}$ We observed the mutant Ubp-M enzyme expressed at high levels did not cause uH2A deubiquitination, while expression of the active Ubp-M enzyme promoted deubiquitination of $\mathrm{uH} 2 \mathrm{~A}$ - just the opposite result of what one would expect if $\mathrm{UH} 2 \mathrm{~A}$ deubiquitination occurred as a consequence of cell cycle blockade. Therefore, in the absence of apoptosis, simply blocking the cell cycle does not promote $\mathrm{uH} 2 \mathrm{~A}$ deubiquitination. We conclude that a mechanism other than cell cycle blockade must be responsible for the extensive $\mathrm{uH} 2 \mathrm{~A}$ deubiquitination in cells exposed to apoptogenic agents.

It should be noted that $\mathrm{uH} 2 \mathrm{~A}$ deubiquitination, as a single event, does not appear to be sufficient to initiate apoptosis. In fact, the reversible enzymatic trimming of ubiquitin from $\mathrm{uH} 2 \mathrm{~A}$ as chromatin condenses into chromosomes during the normal cell cycle would argue against this possibility. ${ }^{7}$ During cell division, $\mathrm{UH} 2 \mathrm{~A}$ deubiquitination is a wellregulated enzymatic process that is independent of protein-cleaving caspases or destructive DNA-cleaving nucleases. In this regard, early evidence suggests that the deubiquitinating enzyme, Ubp-M, may regulate the timing and organization of condensing mitotic chromosomes by targeting ubiquitinated nucleosomal histones $\mathrm{H} 2 \mathrm{~A}$ and $\mathrm{H} 2 \mathrm{~B}$. ${ }^{9}$ In our hands, cells transiently transfected with the gene for the active Ubp-M-GFP fusion protein had substantially 
decreased nucleosomal uH2A levels. However, these cells failed to exhibit morphological changes characteristic of apoptosis, and neither caspase-3 activation nor caspasedependent PARP cleavage were observed. These results argue that deubiquitination of $\mathrm{uH} 2 \mathrm{~A}$, as an independent biochemical event, does not initiate the apoptotic program, but instead, occurs down-stream of caspase cascade activation during the execution phase of apoptosis.

When viewed in a broader perspective, the results presented here raise the intriguing possibility that $\mathrm{uH} 2 \mathrm{~A}$ deubiquitination might be a survival-response mechanism cells use in an attempt to protect their genomic integrity when confronted with noxious agents. If nucleosomal $\mathrm{uH} 2 \mathrm{~A}$ deubiquitination constitutes an evolutionary conserved genomic protection survival strategy, then cleavage of ubiquitin from $\mathrm{uH} 2 \mathrm{~A}$ might be an unavoidable cellular response to the complex biochemical program that occurs during apoptosis. If this concept is valid, then cleavage of ubiquitination from nucleosomal uH2A might be considered as a 'nuclear sensor of cellular stress' rather than simply a novel enzymatic histone modification that takes place in chromatin as a consequence of caspase activation during apoptosis.

\section{Materials and Methods}

\section{Cell lines and drug treatments}

Jurkat human T lymphoblastic cells, human MCF-7 breast carcinoma, PC-3 prostate tumor and 293 epithelial kidney cells from ATCC (Rockville, MD, USA) and A2780/CP-70 ovarian carcinoma cells (provided by Dr. Eddie Reed, NCl, NIH, Bethesda, MD, USA) were propagated in RPMI 1640 medium supplemented with 10\% heatinactivated fetal bovine serum, $2 \mathrm{mM}$ glutamine, $10 \mathrm{mM}$ HEPES, $\mathrm{pH} 7.5$, under a water-saturated $5 \% \mathrm{CO}_{2}$ atmosphere at $37^{\circ} \mathrm{C}$. Jurkat cells over-expressing Bcl-xL protein (obtained from Dr. Michael Birrer, $\mathrm{NCI}, \mathrm{NIH}$, Bethesda, MD, USA) were grown in complete RPMI medium supplemented with $0.5 \mathrm{~g} / \mathrm{l}$ geneticin (G418, Gibco/BRL). Subconfluent, exponentially growing cells were exposed to anti-Fas activating $A b$, which initiates Fas death domain signalling; the protein kinase $\mathrm{C}$ inhibitor, staurosporine; topoisomerase inhibitors, doxorubicin and etoposide (VP-16), and the proteasome/calpain protease inhibitor, N-acetyl-leucyl-leucyl-norlucinal (ALLnL) in broad concentration ranges and for various times (indicated in legends). Etoposide, staurosporine and ALLnL were dissolved in DMSO; control cells were treated with $0.5 \% \mathrm{v} / \mathrm{v}$ DMSO, the highest concentration of DMSO used, for equivalent times.

\section{Chemicals and immuno-reagents}

ALLnL, VP-16, staurosporine, anti-ubiquitin polyclonal antibody and common laboratory chemicals were purchased from Sigma Chemical Co. (St. Louis, MO, USA) or obtained from the NIH central stockroom. Doxorubicin was obtained from the Drug Development Branch, Division of Cancer Treatment, NCl, NIH (Bethesda, MD, USA). AntiFAS activating antibody and anti-PARP antibody were from Upstate Biotechnology, Inc (Lake Placid, NY, USA). Horseradish peroxidaseconjugated donkey anti-rabbit and sheep anti-mouse secondary antibodies were from Amersham Life Science (Arlington Heights, IL, USA), and anti-GFP monoclonal antibody was from Santa Cruz Biotechnology (Santa Cruz, CA, USA).

\section{Transfection of Ubp-M}

Plasmids containing gene sequences coding for either active or mutation-inactivated human Ubp-M deubiquitinating thiol proteases as Flag-tagged, GFP fusion proteins inserted into the pEGFP-C1 expression vector (Clontech Labs, Inc., Palo Alto, CA, USA) were kindly supplied by Dr. VT Marchesi (Yale University School of Medicine, New Haven, CT). Human kidney 293 cells were transfected (4 $\mu \mathrm{g}$ of DNA per $\mathrm{ml}$ ) using Lipofectamine Plus Reagent (GIBCO BRL, Rockville, MD, USA) according to the manufacturer's protocol. The tranfection efficiency was estimated to be nearly $70 \%$ by counting cells showing GFP fluorescence. The relative expression of the active and mutant Ubp-M-GFP fusion proteins was also evaluated by GFPimmunoblotting of chromatin and clarified lysate fractions following $10 \%$ SDS-PAGE.

\section{Cell lysis and fractionation}

At the termination of incubations, cells were centrifuged at $600 \times g$, washed twice by re-suspension ice-cold PBS, then lysed at $4{ }^{\circ} \mathrm{C}$ in TNESV lysis buffer $(50 \mathrm{mM}$ Tris- $\mathrm{HCl}, \mathrm{pH} 7.5,1 \% \mathrm{v} / \mathrm{v}$ Nonidet P-40, $2 \mathrm{mM}$ EDTA, $100 \mathrm{mM} \mathrm{NaCl}, 10 \mathrm{mM}$ orthovanadate supplemented with $1 \mathrm{mM}$ phenylmethylsulfonyl fluoride, $20 \mu \mathrm{g} / \mathrm{ml}$ of leupeptin and $20 \mu \mathrm{g} /$ $\mathrm{ml}$ aprotinin protease inhibitor cocktail). The crude NP-40-insoluble predominantly nucleoprotein fraction was isolated by centrifugation at $14000 \times g$ for $20 \mathrm{~min}$ at $4^{\circ} \mathrm{C}$, and the supernatant was transferred to a fresh tube and referred to as 'clarified lysate'. The pellets containing the chromatin were washed in $200 \mu$ of TNESV, re-centrifuged, then re-suspended in 0.3 to $0.5 \mathrm{ml}$ of TNESV with protease inhibitors by sonication twice for $10 \mathrm{~s}$ at $50 \mathrm{~W}$ on ice. In some experiments, intact nuclei were isolated after cells were washed in ice-cold PBS and ruptured with a Dounce homogenizer into nuclei isolation buffer (100 mM NaCl, $10 \mathrm{mM}$ Tris, $\mathrm{pH} 7.5,5 \mathrm{mM}$ sodium butyrate, $10 \mathrm{mM}$ iodoacetamide and $0.1 \% \mathrm{v} / \mathrm{v} \mathrm{NP}-40$, supplemented with $1 \mathrm{mM}$ phenylmethanesulfonyl fluoride and $10 \mu \mathrm{g} / \mathrm{ml}$ of aprotinin and leupeptin) prior to precipitating chromatin by adding TESV containing $1 \% \mathrm{v} / \mathrm{v}$ NP-40. Protein concentrations were measured by the bicinchoninic acid microplate method using bovine serum albumin as the standard. ${ }^{36}$

\section{Immunoblotting analysis}

After resolving $100 \mu \mathrm{g}$ aliquots of clarified lysate and 20 to $100 \mu \mathrm{g}$ of chromatin preparations by either 10 or $16 \%$ SDS-PAGE, proteins were electro-transferred to nitrocellulose membranes (Protran ${ }^{\mathrm{TM}}$, Schleicher and Schuell, Keene, NH, USA) by the wet 'Towbin' procedure, ${ }^{37}$ in $25 \mathrm{mM}$ Tris, $190 \mathrm{mM}$ glycine, $0.15 \%$ SDS, $20 \%$ methanol buffer at $4{ }^{\circ} \mathrm{C}$ overnight at $55 \mathrm{~V}$. Membranes intended for anti-ubiquitin immunoblots were sandwiched between several sheets of Whatman 3MM paper, submerged in deionized water and ubiquitin on the membrane was heat-activated by autoclaving for $30 \mathrm{~min}$. This process heat-denatures unconjugated ubiquitin, $\mathrm{uH} 2 \mathrm{~A}$ and other ubiquitinated proteins, which enhances antigenic site recognition by the anti-ubiquitin antibody. ${ }^{38}$ After blocking membranes with $5 \%$ fatfree dry milk in $10 \mathrm{mM}$ Tris, $\mathrm{pH} 7.5,50 \mathrm{mM} \mathrm{NaCl}, 2.5 \mathrm{mM}$ EDTA buffer, $\mathrm{uH} 2 \mathrm{~A}$, high molecular weight ubiquitinated proteins and PARP were immunoblotted with appropriate primary antibodies followed by horseradish peroxidase-conjugated secondary antibodies. Visualization of HRP-linked immune complexes was by chemiluminescence, ${ }^{39}$ using a luminol-based commercial kit from Pierce (Rockford, IL, USA). Exposed X-OMAT ${ }^{\mathrm{TM}}$ AR films (Eastman Kodak Co., Rochester, NY, USA) were developed and scanned (Scanmaker III, Microtek, Redondo Beach, CA, USA), and the images were processed with a 
Macintosh $^{\text {TM }}$ computer using Adobe Photoshop 3.0 and Microsoft PowerPoint 98 software.

To immunoblot unconjugated ubiquitin, cells were rinsed with icecold PBS, centrifuged, re-suspended in $1.0 \mathrm{ml} \mathrm{PBS}$, then boiled for $10 \mathrm{~min}$ in a water bath to inactivate ubiquitin-cleaving isopeptidases and to denature ubiquitin-containing proteins. The samples were then chilled on ice and centrifuged at $14000 \times \mathrm{g}$ for $10 \mathrm{~min}$. Aliquots of the clarified supernatants $(25 \mu \mathrm{g})$ were resolved by $15 \%$ SDS-PAGE, the gels were equilibrated at room temperature for $\sim 30 \mathrm{~min}$ in $65 \mathrm{mM}$ Tris, $\mathrm{pH} 6.8,2.3 \%$ SDS, 5\% 2-mercaptoethanol, and electrotransferred overnight at $50 \mathrm{~V}$ and $4^{\circ} \mathrm{C}$ onto nitrocellulose membranes in 'alkaline transfer' buffer: $25 \mathrm{mM}$ cyclohexylaminopropane sulfonic acid, $\mathrm{pH} 10$, containing $20 \%$ methanol. ${ }^{40,41}$

\section{Evaluation of cellular histone status during apoptosis}

Jurkat cells were treated with $5 \mu \mathrm{M}$ doxorubicin or $10 \mu \mathrm{M}$ etoposide for $20 \mathrm{~h}$ or $1 \mu \mathrm{M}$ staurosporine for $15 \mathrm{~h}$ to induce apoptosis; control cells were exposed to $0.5 \% \mathrm{v} / \mathrm{v}$ DMSO. Cells were collected by centrifugation, washed by re-suspension in ice-cold PBS and ruptured in $1.0 \mathrm{ml}$ of nuclei isolation buffer $(10 \mathrm{mM}$ Tris, $\mathrm{pH} 7.5 ; 100 \mathrm{mM} \mathrm{KCl}$, $5 \mathrm{mM}$ sodium butyrate, $10 \mathrm{mM}$ iodoacetamide containing $0.1 \% \mathrm{v} / \mathrm{v} \mathrm{NP}$ 40 detergent and a cocktail of protease inhibitors) using 20 strokes of a Dounce homogenizer. Nuclei were isolated by centrifugation at $900 \times g$ for $10 \mathrm{~min}$, washed in PBS and re-suspended in $400 \mu \mathrm{l}$ of nuclei isolation buffer. Histones were extracted from isolated nuclei by adding an equivalent volume of $0.8 \mathrm{~N}$ sulfuric acid, chilling the samples on ice for $30 \mathrm{~min}$ with intermittent mixing, and the samples were centrifuged at $10000 \times \mathrm{g}$ for $10 \mathrm{~min}$ to sediment denatured acidinsoluble proteins. The acid-extracted histones in the supernatant fraction were dialyzed against several changes of $0.1 \mathrm{~N}$ acetic acid, lyophilized, reconstituted into histone sample buffer $(6.0 \mathrm{M}$ urea, $1.5 \mathrm{M}$ potassium acetate, $\mathrm{pH} 4.5,20 \%$ glycerol with a small amount of methylene blue tracking dye) and electrophoretically separated on $0.96 \mathrm{~N}$ acetic acid, $6.7 \mathrm{M}$ urea, $6 \mathrm{mM}$ Triton X-100 (AUT) $15 \%$ polyacrylamide gels, essentially as described, ${ }^{40,42,43}$ except that $0.1 \mathrm{M}$ glycine was added to the $0.9 \mathrm{M}$ acetic acid gel running buffer. ${ }^{44}$ Histones migrate to the cathode in AUT-polyacrylamide gels. Purified histone $\mathrm{H} 2 \mathrm{~A}$ and $\mathrm{H} 2 \mathrm{~B}$ reference standards were included on gels with the extracted histones for comparison. Following electrophoresis, histones were stained in the gel with $0.25 \%$ Comassie Brillant Blue R250 dye in $50 \%$ methanol- $10 \%$ acetic acid. The amount of uH2A in the extracted histones from control and apoptotic cells was also evaluated by anti-ubiquitin immunoblotting following standard $15 \%$ SDS-PAGE.

\section{Caspase-3 assay}

The caspase-3-dependent conversion of the substrate, $\mathrm{N}$-acetyl-AspGlu-Val-Asp-AMC (7-amino-4-methylcoumarin) peptide (Ac-DEVDAMC) to its fluorescent product in the presence of $20-50 \mu \mathrm{g}$ of clarified cell TNESV lysate was measured in a 96-well plate in $200 \mu \mathrm{l}$ of $20 \mathrm{mM}$ HEPES, $\mathrm{pH} 7.5 ; 10 \% \mathrm{v} / \mathrm{v}$ glycerol; $2 \mathrm{mM}$ DTT reaction buffer, with a Wallac Victor ${ }^{2}$ model 1420 fluorescence counter at $460 \mathrm{~nm}$, exactly according to the manufacturer's directions (PharMingen, San Diego, CA, USA).

\section{Morphological evaluation by light microscopy}

Prior to cell lysis, aliquots of control and treated Jurkat cells were transferred into 96-well plates and cell lethality was determined by counting the number of cells stained with $0.02 \%$ Trypan-blue dye.
Images were captured using a digital camera, Macintosh computer and Adobe Photoshop 3.0 software. The percentage of cells with the apoptotic phenotype of multiple plasma membrane blebs, cell shrinkage, chromatin condensation and fragmentation were estimated by examining several hundred cells in multiple fields. Apoptotic bodies were frequently observed during late stages of apoptosis when the percent of Trypan blue positive cells exceeded $\sim 25 \%$.

\section{Fluorescence microscopy}

Chromatin condensation and fragmentation in cells undergoing apoptosis were evaluated by fluorescence microscopy after fixing cells with paraformaldehyde and staining chromatin with 4,6-diamidino-2-phenylindole (DAPI) dye at $1.0 \mu \mathrm{g} / \mathrm{ml} .{ }^{45,46}$ Transfection expression efficiency and the intracellular localization of the active GFP-Ubp-M and mutated GFP-Ubp-M fusion protein constructs were evaluated by comparing GFP fluorescence in cells using an appropriate filter.

\section{Acknowledgements}

The authors thank Dr. Michael Birrer, $\mathrm{NCl}, \mathrm{NIH}$, for providing the $\mathrm{Bcl}-\mathrm{xL}$ over-expressing and empty vector-transfected Jurkat cells and Dr. Vincent Marchesi, Yale University, for providing vectors containing inserts for the Ubp-M and mutant inactive Ubp-M deubiquitinating enzymes.

\section{References}

1. Nickel BE, Allis CD and Davie JR (1989) Ubiquitinated histone H2B is preferentially located in transcriptionally active chromatin. Biochemistry 28 : $958-963$

2. Davie JR and Murphy LC (1990) Level of ubiquitinated histone H2B in chromatin is coupled to ongoing transcription. Biochemistry 29: $4752-4757$

3. Li W, Nagaraja S, Delcuve GP, Hendzel MJ and Davie JR (1993) Effects of histone acetylation, ubiquitination and variants on nucleosome stability. Biochem. J. 296: 737-744

4. Wu RS, Kohn KW and Bonner WM (1981) Metabolism of ubiquitinated histones. J. Biol. Chem. 256: 5916-5920

5. Seale R (1981) Rapid turnover of the histone-ubiquitin conjugate, protein A24. Nucleic Acid Research 9: 3151-3158

6. Louters L and Chalkley $\mathrm{R}(1985)$ Exchange of histones $\mathrm{H} 1, \mathrm{H} 2 \mathrm{~A}$, and $\mathrm{H} 2 \mathrm{~B}$ in vivo. Biochemistry 24: 3080-3085

7. Mueller RD, Yasuda H, Hatch CL, Bonner WM and Bradbury EM (1985) Identification of ubiquitinated histones $2 \mathrm{~A}$ and $2 \mathrm{~B}$ in Physarum polycephalum. J. Biol. Chem. 260: 5147-5153

8. Bradbury EM (1992) Reversible histone modifications and the chromosome cell cycle. Bioessays 14: 9-16

9. Cai S-Y, Babbitt RW and Marchesi VT (1999) A mutant deubiquitinating enzyme (Ubp-M) associates with mitotic chromosomes and blocks cell division. Proc. Natl. Acad. Sci. USA 96: 2828-2833

10. Marushige $Y$ and Marushige $K$ (1995) Disappearance of ubiquitinated histone $\mathrm{H} 2 \mathrm{~A}$ during chromatin condensation in TGFB1-induced apoptosis. Anticancer Res. 15: $267-272$

11. Tanimoto $Y$, Onishi $Y$, Hashimoto $S$ and Kizaki H (1997) Peptidyl aldehyde inhibitors of proteasome induce apoptosis rapidly in mouse lymphoma RVC cells. J. Biochem. 121: $542-549$

12. Mimnaugh EG, Chen HY, Davie JR, Celis JE and Neckers L (1997) Rapid deubiquitination of nucleosomal histones in human tumor cells caused by proteasome inhibitors and stress response inducers: effects on replication, transcription, translation, and the cellular stress response. Biochemistry 36 : $14418-14429$ 
13. Mimnaugh EG, Yunmbam MK, Li Q, Bonvini P, Hwang S, Trepel J, Reed E and Neckers $L$ (2000) Prevention of cisplatin-DNA adduct repair and potentiation of cisplatin-induced apoptosis in ovarian carcinoma cells by proteasome inhibitors. Biochem. Pharmacol. 60: 1343-1354

14. Yang Y, Fang S, Jensen JP, Weissman AM and Ashwell JD (2000) Ubiquitin protein ligase activity of IAPs and their degradation in proteasomes in response to apoptotic stimuli. Science 288: $874-877$

15. Huang $\mathrm{H}$, Joazeiro CA, Bonfoco E, Kamada S, Leverson JD and Hunter T (2000) The inhibitor of apoptosis, clAP2, functions as a ubiquitin-protein ligase and promotes in vitro monoubiquitination of caspases 3 and 7. J. Biol. Chem. 275: 26661-26664

16. Adams JM and Cory S (1998) The Bcl-2 protein family: arbiters of cell survival. Science 281: $1322-1326$

17. Vander Heiden MG and Thompson CB (1999) Bcl-2 proteins: regulators of apoptosis or of mitochondrial homeostasis? Nat. Cell. Biol. 1: E209-E216

18. Antonsson B and Martinou JC (2000) The Bcl-2 protein family. Exp. Cell Res. 256: $50-57$

19. Newmeyer DD, Bossy-Wetzel E, Kluck RM, Wolf BB, Beere HM and Green DR (2000) Bcl-xL does not inhibit the function of Apaf-1. Cell Death Differ. 7: 402407

20. Soldatenkov VA and Dritschilo A (1997) Apoptosis of Ewing's sarcoma cells is accompanied by accumulation of ubiquitinated proteins. Cancer Res. 57:38813885

21. Soldatenkov VA, Prasad S, Voloshin Y and Dritschilo A (1998) Sodium butyrate induces apoptosis and accumulation of ubiquitinated proteins in human breast carcinoma cells. Cell Death Differ. 5: 307-312

22. Haas AL, Bright PM and Jackson VE (1988) Functional diversity among putative E2 isozymes in the mechanism of ubiquitin-histone ligation. J. Biol. Chem. 263: $13268-13275$

23. Hershko A and Ciechanover A (1998) The ubiquitin system. Annu. Rev. Biochem. 67: 425-479

24. Wilkinson KD (1997) Regulation of ubiquitin-dependent processes by deubiquitinating enzymes. FASEB J. 11: 1245-1256

25. D'Andrea A and Pellman D (1998) Deubiquitinating enzymes: a new class of biological regulators. Crit. Rev. Biochem. Molec. Biol. 33: 337-352

26. Matsui S, Seon BK and Sandberg AA (1979) Disappearance of a structura chromatin protein A24 in mitosis: Implications for molecular basis of chromatin condensation. Proc. Natl. Acad. Sci. USA 76: 6386-6390

27. Kanda F, Matsui S, Sykes DE and Sandberg AA (1984) Affinity of chromatin constituents for isopeptidase. Biochem. Biophys. Res. Commun. 122: 12961306

28. Harvey KF, Harvey NL, Michael JM, Parasivam G, Waterhouse N, Alnemri ES Watters D and Kumar S (1998) Caspase-mediated cleavage of the ubiquitinprotein ligase Nedd4 during apoptosis. J. Biol. Chem. 273: 13524-13530

29. Cohen GM (1997) Caspases: the executioners of apoptosis. Biochem. J. 326 $1-16$
30. Nicholson DW (1999) Caspase structure, proteolytic substrates, and function during apoptotic cell death. Cell Death Differ. 6: 1028-1042

31. Earnshaw WC, Martins LM and Kaufmann SH (1999) Mammalian caspases: structure, activation, substrates, and functions during apoptosis. Annu. Rev. Biochem. 68: 383-424

32. Johnston JA, Ward CL and Kopito RR (1998) Aggresomes: a cellular response to misfolded proteins. J. Cell Biol. 143: 1883-1898

33. Kopito RR (2000) Aggresomes, inclusion bodies and protein aggregation. Trends Cell Biol. 10: 524-530

34. Rogakou EP, Nieves-Neira W, Boon C, Pommier Y and Bonner WM (2000) Initiation of DNA fragmentation during apoptosis induces phosphorylation of H2AX histone at serine 139. J. Biol. Chem. 275: 9390-9395

35. Ortolan TG, Tongaonkar $\mathrm{P}$, Lambertson $\mathrm{D}$, Chen L, Schauber $\mathrm{C}$ and Madura $\mathrm{K}$ (2000) The DNA repair protein Rad23 is a negative regulator of multi-ubiquitin chain assembly. Nat. Cell. Biol. 2: 601-608

36. Smith PK, Krohn RI, Hermanson GT, Mallia AK, Gartner FH, Provenzano MD, Fujimoto EK, Goeke NM, Olson BJ and Klenk DC (1985) BCA protein assay. Anal. Biochem. 150: 76-85

37. Towbin H, Staehelin T and Gordon J (1979) Electrophoretic transfer of proteins form polyacrylamide gels to nitrocellulose sheets: Procedure and some applications. Proc. Natl. Acad. Sci. 76: 4350-4365

38. Swerdlow PS, Finley D and Varshavsky A (1986) Enhancement of immunoblot sensitivity by heating of hydrated filters. Anal. Biochem. 156: 147-153

39. Bobrow MN, Harris TD, Shaughnessy KJ and Litt GJ (1989) Catalyzed reporter disposition, a novel method of signal amplification. J. Immunol. Methods 125: $279-285$

40. Delcuve GP and Davie JR (1992) Western blotting and immunochemical detection of histones electrophoretically resolved on acid-urea-triton-and sodium dodecyl sulfate-polyacrylamide gels. Anal. Biochem. 200: 339-341

41. Mimnaugh EG, Bonvini $P$ and Neckers $L$ (1999) The measurement of ubiquitin and ubiquitinated proteins. Electrophoresis 20: 418-428

42. Zweidler A (1978) Resolution of histones by polyacrylamide gel electrophoresis in presence of nonionic detergents. Methods Cell Biol. 17: 223-233

43. Davie JR and NickelBE (1987) The ubiquitinated histone species are enriched in histone H1-depleted chromatin regions. Biochem. Biophys. Acta. 909: 183-189

44. Rogakou EP, Pilch DR, Orr AH, Ivanova VS and BonnerWM (1998) DNA doublestrand breaks induce histone H2AX phosphorylation on serine 139. J. Biol. Chem. 273: $5858-5868$

45. Cowden RR and Curtis SK (1981) Microfluorometric investigations of chromatin structure. I. Evaluation of nine DNA-specific fluorochromes as probes of chromatin organization. Histochemistry 72: 11-23

46. Suzuki N, Urano J and Tamanoi F (1998) Farnesyltransferase inhibitors induce cytochrome $c$ release and caspase 3 activation preferentially in transformed cells. Proc. Natl. Acad. Sci. USA 95: 15356-15361 